\title{
Medicinal plants and phytotherapy in Iran: Glorious history, current status and future prospects
}

\author{
Mohammad Sadegh Amiri ${ }^{*}$, Mohammad Ehsan Taghavizadeh Yazdi² \& Mostafa Rahnama ${ }^{3}$ \\ ${ }^{1}$ Department of Biology, Payame Noor University, Tehran, Iran \\ ${ }^{2}$ Medical Toxicology Research Center, School of Medicine, Mashhad University of Medical Sciences, Mashhad, Iran \\ ${ }^{3}$ Department of Plant Pathology, University of Kentucky, Lexington, KY 40506, USA \\ *Email: amiriherb@gmail.com
}

\section{ARTICLE HISTORY}

Received: 24 August 2020

Accepted: 10 October 2020

Published: 01 January 2021

\section{KEYWORDS}

Medicinal plants

Challenges

Traditional medicine

Conservation

Iran

\section{ABSTRACT}

This study is an endeavour to analyse the status of medicinal plants research in Iran. Because of its exceptional phytogeography, Iran has a unique and diverse flora. It is estimated that, 8167 species of vascular plants are present in Iran of which about 2075 have medicinal importance. Situated at the heart of the Silk Road, Iran enjoys a mix of cultures providing a rich backbone for the development of traditional herbal medicine practices. Notwithstanding the brilliant history in traditional medicine and success of investigation to produce herbal medicines, attempts in recent decades, face many challenges. Many text and paper about these concerns were never translated in English. Strong need was felt to record such data of medicinal plants of Iran, their conservation status and related information. The scattered literature over medicinal plants of Iran were collected, analysed and presented in this review, highlighting not only their therapeutic potential but also concerns about product authenticity, quality, safety and efficacy. This will provide ways for future scientific research in this area. Awareness of critical issues in traditional medicinal herbs can play a pivotal role in the discovery and development of plant based drugs and to sustain consumer confidence.

\section{Introduction}

Iran covers an area of about 1.6 million square kilometre. It is situated between Central Asia and Himalaya in the east and Caucasus and Anatolia in the west. Altitudinally, it ranges from $26 \mathrm{~m}$ b.s.l. along the shore of the Caspian Sea up to $5671 \mathrm{~m}$ a.s.l. at Damavand Mountain in centre of Alborz. Climatically, it contrasts from humid to subtropical humid weathers, varying from hot/dry deserts with rainfall of not more than $25 \mathrm{~mm} / \mathrm{yr}$ in central areas to southern coast of the Caspian Sea with rainfall more than 1800 $\mathrm{mm} / \mathrm{yr}(1)$.

Iran has very rich botanical wealth and plant diversity, because of its considerable phytogeographical position amidst three main phytochoria of the Old World, including IranoTuranian, Euro-Siberian and Saharo-Sindian, and influences by Mediterranean and Somalia-Masaei species (2-4). The Iranian Plateau is considered as a bridge for migration of numerous plant species, linking the eastern and western floras of Eurasia (1).

Out of 308312 vascular plants species on earth, over 80000 herbal species are being employed in folk medicines for therapeutic purposes $(5,6)$. The flora of Iran is rich regarding to its number of plant species. It is estimated that 8167 species of vascular plants are present in Iran, of these about 2597 species are (sub) endemic $(1,7)$.

It is also a rich country in terms of medicinal and aromatic plants and it has been estimated that Iranian flora contains about 2075 medicinal plant species with phytochemical and therapeutic potential (8). Among them, about 400-500 medicinal plant species are utilized by native people in traditional and folk medicines in various regions of the country (8). Iran is known for its great diversity of Artemisia L. and Astragalus L. that are renowned for their medicinal and cosmetic properties $(8,9)$.

(c) Amiri et al (2021). This is an open-access article distributed under the terms of the Creative Commons Attribution License, which permits unrestricted use, distribution and reproduction in any medium, provided the original author and source are credited (https://creativecommons.org/licenses/by/4.0/).

To cite this article: Amiri M S, Yazdi M E T, Rahnama M. Medicinal plants and phytotherapy in Iran: Glorious history, current status and future prospects. Plant Science Today. 2021;8(1):95-111. https://doi.org/10.14719/pst.2021.8.1.926 
Over the past few decades, there is increase in the usage of folk remedies in the world, particularly in herbal products. According to the World Health Organization (WHO) for primary healthcare needs, $60 \%$ of world's population is dependent on traditional drugs and $80 \%$ people of developing countries is dependent on medicinal plants to get herbal drugs (10).

In Iran, similar to many other countries, we have observed growing interest to use of traditional medicine. Iranian Traditional Medicine (ITM) is largely based on the Unani system, which is a good example of the oldest medical systems from ancient Persia. It is a holistic approach for prevention and treatment of various ailments that is mainly derived from medicinal plants and also other natural resources like minerals, metallic and animal origin. Iran is among the seven countries in Asia with the maximal use of medicinal herbs. There are over 130 plant-based medicines in Iran (8). Nowadays traditional medicine in Iran is still linked to the local ethnobotanical studies. Ethnobotanical surveys, carried out throughout the Iranian territory confirm that medicinal plants are the major component of ITM (11).

However, despite the rich knowledge that lies behind the traditional uses of the Iranian medicinal plants, few attempts have been made to evaluate the key issues that these herbs face in the country.

Therefore, this study presents the first comprehensive report associated with the status of medicinal plants in Iran. The review highlights the significant role of the Iranian medicinal plants in primary healthcare system, and also focuses on the recent serious challenges in product authenticity, quality, safety, efficacy, identification and authentication of them. A considerable part of this paper is dedicated to the identification and authentication challenges of Iranian medicinal plants. The conservation status of Iranian medicinal flora, their sustainable utilization and protection of the related traditional knowledge have also been discussed. The gaps in knowledge are identified, and prospects for further investigations are recommended in the context of ethnobotany and medicinal plants.

A holistic search of scientific content data-bases such as PubMed/Medline, Google Scholar, Scopus and Science Direct, English and non-English reference books was made. After a comprehensive survey, a total of 107 publications that described valuable data dealing with the different aspects of medicinal plants and traditional medicine in Iran were reviewed. Author and scientific names of all the documented plant taxa were carefully scrutinized for most recent alterations via "The Plant List" (http://www.theplantlist.org).

\section{Traditional medicinal systems: the global view}

Traditional medicine is a cultural database that embedded in the knowledge of human societies and is the entirety of information, expertnesses and practices according to the principles, faiths and experiences indigenous to various cultures that are employed to preserve health, as well as to hinder, diagnose, ameliorate or remedy physical and mental diseases. Folk medicine that has been accepted by other people (outside its aboriginal culture) is often called complementary and alternative medicine (CAM) $(12,13)$.

Since ancient times, various categories of traditional medicine system, including Traditional Chinese Medicine, Iranian Traditional Medicine (also known as Persian medicine), Islamic Traditional Medicine, Traditional Korean Medicine, Traditional African Medicine, Ayurveda, Unani and homeopathy, are the most important and popular traditional methods in providing healthcare around the globe. The core discipline or similarity among all the traditional systems of medicine is herbal medicine, as well named phyto-medicine or phyto-therapy, which is based on the use of plants for therapeutic purposes (6). The first documentary sources for the treatment with medicinal plants are older than the memories. Although the earliest written evidence of therapeutic plants dated back at least 5000 years to the Sumerians, who defined good established therapeutic usages for some plants such as Laurus nobilis L. (Lauraceae), Carum carvi L. (Apiaceae) and Thymus vulgaris L. (Lamiaceae), archaeological surveys have demonstrated that the practice of botanical medicine dates since 6000 years before in Iraq and 8000 years before in China (6).

Among all the different traditional healthcare systems, Traditional Chinese Medicine (TCM) is currently the most commonly, and is gaining importance in the global market. Currently, more than 8000 different kinds of plant derived yields are exported from China to over 130 countries across the world. Recently, China has devoted a great deal of efforts and economic resources to enhance study and progress in the field of Chinese Herbal Medicine which is unmatched by other traditional medicine systems worldwide. Ayurvedic medicine (also known as Indian Herbal Medicine) is intensely rooted in Indian culture, and $70 \%$ of Indians depend on it for major healthcare needs (6). African Traditional Medicine is considered as one of the earliest of the traditional systems of medicine. African traditional healthcare system in its varied forms is holistic involving both the body and the mind. The traditional medicinal practitioners usually identify and treats the psychosomatic source of a sickness before suggesting plant based drugs $(6,13)$.

The people of Islamic countries have a great faith in Islamic Traditional Medicine, which has the history of hundreds of years. The most popular traditional drug in folk medicine practices around the Islamic countries is the use of medicinal plants. In the period of Islamic or the early medieval era, the Iranian scholars and doctors, including Avicenna, Rhazes and Jorjani etc. flourished the medical sciences. Due to these attainments, this era is known as the Islamic Golden Age $(6,14)$.

Some of the most celebrated scholars and physicians who were instrumental in the development of Islamic countries are indicated in Table 1 (15). 
Table 1. Some of the most important scholars and relevant texts in the Islamic Traditional Medicine

\begin{tabular}{|c|c|c|c|}
\hline Islamic scholars & Book & Language & Living period \\
\hline Ahwazi Arjâni, AA. & Kamel al-Sinâh aț-Ṭibbiyah & Arabic & 930-994 C.E \\
\hline Akhawayni Bukhari, RA. & Hidâyat-al-Mutâllimin fi aț-Ṭibbe & Persian & 10th century \\
\hline Antaki, DO. & Tadֵkirat Oli al-Albâb wa al-Jâme le al-Ajb al-Ujâb & Arabic & 1535-1599 C.E. \\
\hline Ansâri, AH. & Ekhtiyârât Badi i & Persian & ?-1403 C.E. \\
\hline Aqili Khorasani, MH. & Makhzan al-Adwiah & Persian & 18th century \\
\hline Biruni, MA. & Aṣ-Ṣaydanah & Arabic & 973-1048 C.E. \\
\hline Ghasani, AM. & Ḥadiqat al-Azhâr fi Mâhiyyat al-ushb wa al-uqqâr & Arabic & 1547-1611 C.E. \\
\hline Herawi, AR. & Al-Abniyah an Ḥaqâyeq al-Adwiah & Persian & 10th century \\
\hline Husseini Tonekaboni, MM. & Tohfah al- Mo'menin & Persian & 17th century \\
\hline Ibn Al-Baytâr, AA. & Al-Jâmee le Mofradât al-Adwiah wa al-Aghdiah & Arabic & 1193-1248 C.E. \\
\hline Ibn Nafis Qarshi & Ash -Shamel fi aț-Tibbe & Arabic & 1210-1288 C.E. \\
\hline Ibn Sina, HA. & Al-Qânun fi aț-Țibbe & Arabic & 980-1037 C.E. \\
\hline Jorjâni, SI. & Dakhireh Khârazmshâhi & Persian & 1042-1136 C.E. \\
\hline Jorjâni, SI. & Al-Aghrâḍaț-Ṭibbiah wa al-Mabâhethi al-Alâiiah & Persian & 1042-1136 C.E. \\
\hline Razi, MZ. & Al-Hâwi fi aț-Ṭibbe & Arabic & 865-925 C.E. \\
\hline Tabari, MA. & Ferdows al-Hekmah fi aț-Ṭibbe & Arabic & 773-861 C.E. \\
\hline Torkamâni YO. & al-Mo’tamad fi al-Adwiyah al-Mofradah & Arabic & 1222-1294 C.E. \\
\hline
\end{tabular}

\section{Traditional medicinal system in Iran}

Persia (ancient Iran) is celebrated as one of the earliest civilizations in the world. Iran has a worthy history in traditional medicine, that relate to Babylonian-Assyrian civilization era. Traditional medicine in Iran is largely based on the Unani system, which is a good example of the oldest medical systems from ancient Persia. Also, Iran has long tradition in therapeutic plants usages for the management of different illnesses $(8,11)$. Avicenna (Abu Ali Sina), one of the most well-known doctors and philosopher, wrote 456 books in numerous topics including his most prominent compendium, "Canon of Medicine", which is a reference book in medicine with a special emphasis on plant based drugs. In this invaluable document which is still an authentic reference in a lot of medical schools across the world, about 1500 herbal drugs and almost 800 species of medicinal vascular plants have been discussed in detail. The present form of Unani medicine greatly owes to him (16-18).

According to the basic principles of Iranian Traditional Medicine (based on Unani system of medicine), body is made up of the four basic components including: fire (that is hot), water (wet), earth or soil (dry) and air (cold). Nature or temperament of body is an outcome of mixing four special elements including: blood (which is hot and wet), bile (hot and dry), lymph or phlegm (cold and wet) and atrabilious (cold and dry). Any imbalance in the components of a nature can be resulted in creation of an illness (Fig. 1). In the traditional healthcare system of Iran, medicinal plants are major source of traditional medicine. Herbal medicine is still broadly used in Iran and the Unani system has been accepted and integrated into the national health system $(11,19)$.

\section{Ethnobotany in Iran: Trends and Gaps}

Ethno-botany is the organized survey of plants and their applied usages through the folklore information of an autochthonous culture and people. Iran is not only rich in its biodiversity but it is also well known as a country with high diversity ethnicities. Iran is a multi-ethnicity

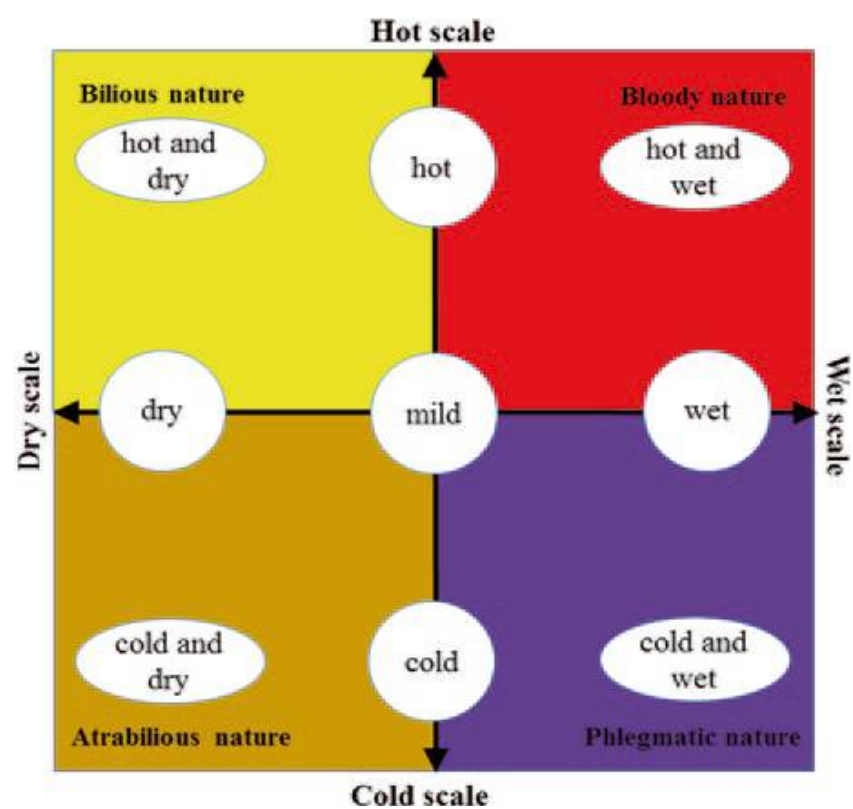

Fig.1. Schematic diagram of human nature in Iranian Traditional Medicine.

country with various ethnic groups such as Persians, Turkic Arabs, Turkmen, Lurs, Kurds and Baluchs communities. Thus, it enjoys a mix of cultures which is considered as a rich backbone for the expansion of ethnobotanical knowledge and plant based medicines. The study of traditional uses of medicinal plants is a major part of ethnobotany which is known as medical ethnobotany, ethnomedicine or ethnopharmacology (20-22).

Historic sign demonstrates the fact that Iranians are one of the earliest people in consuming the medicinal plants. The origin of Iranian therapeutic ethnobotany can be found in the distant periods. The first doctor trained in the universe was an Iranian named Sryta, whose name has been stated in the book of Avesta, the most ancient scriptures of Zoroastrianism). Therefore, the framework of Iranian ethnomedicine and medical ethnobotany are rooted in ancient times $(23,24)$. 
In the last decades, several ethnobotanical investigations have been reported in various geographical regions of the country $(9,11,25-33)$. Ethnobotanical studies carried out throughout the Iranian territory confirmed that medicinal plants are the major component of Iranian Traditional Medicine. Nowadays, in all towns and rural areas, there are medicinal plant or product stores (called Attari), where traditional medical practitioners (Attars) give receipts and sell therapeutic plants (11).

Medicinal herbs of Iran are used to treat various types of illnesses and health conditions, which are grouped in 12 broad categories according to WHO's International Classifications of Disease (34), that could be adapted to ethnobotanical surveys. Table 2 details the most efficient medicinal plants of Iran for the treatment of different ailments.
The analysis of researches related to ethnomedicinal plants published from 2004 to 2016 revealed that, although a broad array of diseases was stated for those plants, digestive system diseases $(30.15 \%)$ and respiratory illnesses $(14.28 \%)$, were the most cited (21).

According to literature review in the Iranian territory, the ethnobotanical research gaps include two main issues; the lack of scientific identification and insufficient statistical information.

Ethnobotany has always been to some extent an interdisciplinary science. In Iran, most ethnobotanical surveys have been conducted by pharmacognosists and anthropologists and botanists are not actually involved in this interdisciplinary field (35). However, the ethnobotany and

Table 2. The most efficient medicinal plants of Iran for treating ailments.

\begin{tabular}{|c|c|c|c|}
\hline No. & Ailment categories & Taxon name & References \\
\hline 1 & $\begin{array}{l}\text { Digestive system } \\
\text { diseases }\end{array}$ & $\begin{array}{l}\text { Achillea santolinoides subsp. wilhelmsii (K.Koch) Greuter., Anethum graveolens L., } \\
\text { Artemisia dracunculus L., Bunium persicum (Boiss.) B.Fedtsch., Capsicum annuum L., } \\
\text { Cassia fistula L., Curcuma longa L., Curcuma zedoaria (Christm.) Roscoe, Coriandrum } \\
\text { sativum L., Cuminum cyminum L., Dysphania botrys (L.) Mosyakin \& Clemants, Ferula } \\
\text { gummosa Bioss., Foeniculum vulgare Mill., Glycyrrhiza glabra L., Heracleum persicum } \\
\text { Desf. ex Fisch., C.A.Mey. \& Avé-Lall., Laurus nobilis L., Matricaria chamomilla L., } \\
\text { Mentha longifolia (L.) L., Mentha spicata L., Myristica fragrans Houtt., Nigella sativa L., } \\
\text { Ocimum basilicum L., Pimpinella anisum L., Piper longum L., Trachyspermum ammi (L.) } \\
\text { Sprague, Satureja hortensis L., Senna italica Mill., Terminalia chebula Retz., Teucrium } \\
\text { polium L., Ziziphora clinopodioides Lam., Zataria multiflora Boiss. }\end{array}$ & $(26,14,11)$ \\
\hline 2 & $\begin{array}{l}\text { Respiratory } \\
\text { system diseases }\end{array}$ & $\begin{array}{l}\text { Amaranthus caudatus L., Caccinia macranthera (Banks \& Sol.) Brand, Dorema } \\
\text { ammoniacum D.Don, Dysphania botrys (L.) Mosyakin \& Clemants, Echinops cephalotes } \\
\text { DC., Hyssopus officinalis L., Malva neglecta Wallr., Malva sylvestris L., Myrtus } \\
\text { communis L., Nepeta binaloudensis Jamzad, Nepeta bracteata Benth., Nymphaea alba } \\
\text { L., Origanum vulgare L., Papaver rhoeas L., Perovskia abrotanoides Kar., Stachys } \\
\text { lavandulifolia Vahl, Trigonella foenum-graecum L., Tussilago farfara L., Urtica pilulifera } \\
\text { L., Viola odorata L., Zataria multiflora Boiss. }\end{array}$ & $(11,91)$ \\
\hline 3 & $\begin{array}{l}\text { Genitourinary } \\
\text { system diseases }\end{array}$ & $\begin{array}{l}\text { Acorus calamus L., Areca catechu L., Astragalus hamosus L., Prunus avium (L.) L., } \\
\text { Coriandrum sativum L., Crocus sativus L., Gentiana lutea L., Juniperus sabina L., Panax } \\
\text { ginseng C.A.Mey., Petroselinum crispum (Mill.) Fuss, Physalis alkekengi L., Pinus } \\
\text { gerardiana Wall. ex D.Don, Polygonatum orientale Desf., Rheum ribes L., Rosa } \\
\text { beggeriana Schrenk ex Fisch. \& C.A.Mey., Sesamum indicum L., Syzygium aromaticum } \\
\text { (L.) Merr. \& L.M.Perry, Tribulus terrestris L., Zea mays L. }\end{array}$ & $(11,15,92)$ \\
\hline 4 & $\begin{array}{c}\text { Circulatory system } \\
\text { diseases }\end{array}$ & $\begin{array}{l}\text { Echium amoenum Fisch. \& C.A.Mey., Berberis integrrima Bunge, Calendula officinalis } \\
\text { L., Allium sativum L., Camellia sinensis (L.) Kuntze, Centaurea depressa M.Bieb., Citrus } \\
\text { spp., Cucumis sativus L., Descurainia sophia (L.) Webb ex Prantl, Equisetum arvense L., } \\
\text { Rhus coriaria L., Hibiscus sabdariffa L., Physalis alkekengi L., Rheum turkestanicum } \\
\text { Janisch., Ribes khorasanicum Saghafi \& Assadi, Rosa beggeriana Schrenk ex Fisch. \& } \\
\text { C.A.Mey., Urtica dioica L., Vaccinium arctostaphylos L., Viola odorata L. }\end{array}$ & $(11,93-97)$ \\
\hline 5 & $\begin{array}{l}\text { Infectious and } \\
\text { parasitic diseases }\end{array}$ & $\begin{array}{l}\text { Allium cepa L., Allium sativum L., Artemisia absinthium L., Artemisia dracunculus L., } \\
\text { Capparis spinosa L., Coriandrum sativum L., Dorema ammoniacum D.Don, Dysphania } \\
\text { botrys (L.) Mosyakin \& Clemants, Embelia ribes Burm.f., Ferula foetida (Bunge) Regel, } \\
\text { Ferula gummosa Boiss., Helichrysum graveolens (M.Bieb) Sweet, Heracleum persicum } \\
\text { Desf. ex Fisch., C.A.Mey. \& Avé-Lall., Lawsonia inermis L., Mentha longifolia (L.) L., } \\
\text { Mentha spicata L., Nigella sativa L., Ocimum basilicum L., Peganum harmala L., } \\
\text { Perovskia abrotanoides Kar., Rheum turkestanicum Janisch., Satureja hortensis L., } \\
\text { Syzygium aromaticum (L.) Merr. \& L.M.Perry, Terminalia citrina Roxb. ex Fleming, } \\
\text { Tribulus terrestris L., Zataria multiflora Boiss., Ziziphora clinopodioides Lam., } \\
\text { Ziziphora tenuior L. }\end{array}$ & $(11,63,98)$ \\
\hline 6 & $\begin{array}{l}\text { Musculoskeletal } \\
\text { system diseases }\end{array}$ & $\begin{array}{l}\text { Abelmoschus esculentus (L.) Moench, Acacia senegal (L.) Willd., Cinchona officinalis L., } \\
\text { Ephedra major Host, Fritillaria imperialis L., Matricaria chamomilla L., Commiphora } \\
\text { mukul (Hook. ex Stocks) Engl., Rosmarinus officinalis L., Scrophularia striata Boiss., } \\
\text { Urtica dioica L., Zataria multiflora Boiss., Zingiber officinale Roscoe }\end{array}$ & $(11,26)$ \\
\hline 7 & Skin diseases & $\begin{array}{l}\text { Arnebia euchroma (Royle) I.M.Johnst., Calendula officinalis L., Falcaria vulgaris Bernh., } \\
\text { Fumaria vaillantii Loisel., Juglans regia L., Matricaria chamomilla L., Myrtus communis } \\
\text { L., Olea europaea L., Origanum vulgare L., Plantago major L., Sesamum indicum L., } \\
\text { Viola odorata L., Ziziphus spina-christi (L.) Desf. }\end{array}$ & $(11,26)$ \\
\hline 8 & $\begin{array}{l}\text { Pregnancy, } \\
\text { childbirth and the } \\
\text { puerperium }\end{array}$ & $\begin{array}{l}\text { Anastatica hierochuntica L., Anethum graveolens L., Apium graveolens L., Aristolochia } \\
\text { rotunda L., Capparis spinosa L., Carthamus tinctorius L., Crocus sativus L., Curcuma } \\
\text { longa L., Dorema ammoniacum D.Don, Ferula gummosa Boiss., Lupinus luteus L., } \\
\text { Matricaria chamomilla L., Physalis alkekengi L., Rosa foetida Herrm., Ruta graveolens } \\
\text { L., Salix alba L., Salix aegyptiaca L., Vitex negundo L., Zataria multiflora Boiss. }\end{array}$ & $(11,91)$ \\
\hline 9 & $\begin{array}{l}\text { Eye, ear, nose and } \\
\text { throat problems }\end{array}$ & $\begin{array}{l}\text { Adiantum capillus-veneris L., Alcea sp., Cannabis sativa L., Chamaecrista absus (L.) H.S. } \\
\text { Irwin \& Barneby, Cordia myxa L., Cydonia oblonga Mill., Echinops cephalotes DC., } \\
\text { Lepidium sativum L., Malva neglecta Wallr., Malva sylvestris L., Salvia macrosiphon } \\
\text { Boiss. }\end{array}$ & $(11,26)$ \\
\hline
\end{tabular}




\begin{tabular}{|c|c|c|c|}
\hline 10 & $\begin{array}{l}\text { Endocrine and } \\
\text { metabolic diseases }\end{array}$ & $\begin{array}{l}\text { Berberis integrrima Bunge, Coriandrum sativum L., Cichorium intybus L., Cynara } \\
\text { scolymus L., Cassia fistula L., Descurainia sophia (L.) Webb ex Prantl, Alhagi } \\
\text { graecorum Boiss., Alhagi maurorum Medik., Dysphania botrys (L.) Mosyakin \& } \\
\text { Clemants, Malva sylvestris L., Fumaria vaillantii Loisel., Plantago major L., Plantago } \\
\text { ovata Forssk., Adiantum capillus-veneris L., Cotoneaster nummularius Fisch. \& } \\
\text { C.A.Mey., Curcuma longa L., Curcuma zedoaria (Christm.) Roscoe, Salix alba L., Salix } \\
\text { excelsa S.G.Gmel., Nasturtium officinale R. Br., Peganum harmala L., Salvia leriifolia } \\
\text { Benth., Securigera securidaca (L.) Degen \& Dorfl., Silybum marianum (L.) Gaertn., } \\
\text { Rheum ribes L., Rheum turkestanicum Janisch., Rhus coriaria L., Ribes khorasanicum } \\
\text { Saghafi \& Assadi, Rumex acetosella L., Teucrium polium L., Tribulus terrestris L., } \\
\text { Toddalia asiatica (L.) Lam., Trigonella foenum-graecum L., Vaccinium arctostaphylos } \\
\text { L., Viola odorata L., Ziziphus jujuba Miller }\end{array}$ & $(11,14,32,95,99-101)$ \\
\hline 11 & $\begin{array}{l}\text { Injury, wound } \\
\text { healing and fungal } \\
\text { infection }\end{array}$ & $\begin{array}{l}\text { Aloe vera (L.) Burm.f., Althaea officinalis L., Doronicum pardalianches L., Falcaria } \\
\text { vulgaris Bernh., Indigofera argentea Burm.f., Lawsonia inermis L., Malva sylvestris L., } \\
\text { Myrtus communis L., Quercus infectoria Oliv., Trichodesma incanum (Bunge) A.DC., } \\
\text { Tussilago farfara L., Ziziphus spina-christi (L.) Desf. }\end{array}$ & $(11,26)$ \\
\hline 12 & $\begin{array}{l}\text { Nervous system } \\
\text { disorders }\end{array}$ & $\begin{array}{l}\text { Achillea santolinoides subsp. wilhelmsii (K.Koch) Greuter., Aloysia citriodora Palau., } \\
\text { Artemisia dracunculus L., Boswellia sacra Fluek., Citrus } \times \text { aurantium L., Coriandrum } \\
\text { sativum L., Crocus sativus L., Cyperus rotundus L., Dracocephalum lindbergii Rech.f., } \\
\text { Echium amoenum Fisch. \& C.A.Mey., Elettaria cardamomum Maton., Ferula gummosa } \\
\text { Bioss., Hypericum scabrum L., Humulus lupulus L., Lavandula angustifolia Mill., } \\
\text { Melissa officinalis L., Nardostachys jatamansii (D.Don) DC., Panax ginseng C.A.Mey., } \\
\text { Papaver rhoeas L., Passiflora caerulea L., Perovskia abrotanoides Kar., Rosmarinus } \\
\text { officinalis L., Stachys lavandulifolia Vahl., Stachys turcomanica Trautv., Terminalia } \\
\text { chebula Retz., Tilia cordata Mill., Vitex negundo L. }\end{array}$ & $(26,33,56)$ \\
\hline
\end{tabular}

ethnopharmacology researches can contain a few documents with ambiguous details, owing to the absence of taxonomic services or botanical expertise. For example, in the literature review of Iranian ethnobotany, we identified that Astragalus ammodendron Bunge (Fabaceae), Eryngium campestre L. (Apiaceae) and Lavandula binaludensis (this species does not exist) have been recorded for ethnobotanical and ethnopharmacological applications (36-38). However, according to Flora Iranica and recent monographs, these taxa do not exist in Iran $(39,40)$. Hence, accurate identification of plant taxa is the foundation of ethnobotanical investigation and the species must only be validated by a panel of specialists including taxonomists (41).

Moreover, there is a need to compile available information and validation of traditional knowledge through appropriate statistical methodologies to ensure the accuracy of ethnobotanical data.

In the last few decades, with the intention of boost the indicative importance of ethnobotanical surveys, there have been efforts to develop the traditional compilation style method via combining proper measurable ways like multivariate statistical analysis. In modern ethnobotany, such novel scientific approaches can help build the highest quality information and also helps ensure the accuracy and reliability of the information $(26,42)$.

Currently, it was found that majority of the ethnobotanical surveys reported in Iran, devoid of insufficient statistical information (22).

Ethnobotanical works may thus serve as the fastest way to species collection for phytochemical and pharmaceutical surveys and such data should be preserved for the production of plant based medicine research in the future $(31,43)$.

\section{Iranian flora wealth in pharmacological and chemical surveys: a compendium of 2075 medicinal species}

Medicinal plants have served as precious resource of therapeutics since ancient times. Almost 200 years ago, our medical practices were mainly dominated by plant-derived drugs. However, the therapeutic application of plants went into a fast decrement in the West since the appearance of more foreseeable artificial medicines with their rapid properties and facile accessibility. However, as a result of different adverse impacts of synthetic drugs, people are now switching to plant-based medicines for health benefits. Plant derived drugs are known for their wide biological functions and are of immense therapeutic potential in traditional system of medicine (44-46). Recently, the renewed attentiveness to plant-based products research, has resulted in the development of new medicines, such as the earliest antimalarial agent, Quinine isolated from bark of Cinchona officinalis L. (Rubiaceae); Aspirin isolated from Salix species; Digoxin isolated from Digitalis species; Vinca alkaloids-Vinblastine and Vincristine obtained from Catharanthus roseus (L.) G. Don (Apocynaceae); Taxol obtained from Taxus brevifolia Nutt. (Taxaceae), Etoposide and Teniposide obtained from roots of Podophyllum species; Ephedrine isolated from Ephedra species; Artemisinin isolated from Artemisia annua L. (Asteraceae) (the current WHO recommended antimalarial agent); and Metformin isolated from Galega officinalis L. (Fabaceae) (the anti diabetic agent). Aside the therapeutic advantages of plant secondary metabolites, herbal extracts are now broadly used in perfumery and food flavouring as well as agrochemicals and pesticides (47-49).

In recent years, many studies have addressed the pharmacological and chemical properties of plants of Iranian Traditional Medicinal System (32, 44, 50-67).

Iran comprises an immense wealth of medicinal herbs (2075 species) suitable for pharmacological and chemical analysis and this source has not yet been fully evaluated. The vascular flora of Iran possesses a total of 2597 endemic or sub-endemic taxa. Many of these taxa from Fabaceae (687 taxa), Asteraceae (618 taxa), Lamiaceae (155 taxa), Apiaceae (127 taxa) and Brassicaceae (88 taxa) have not been studied well. 
These taxa are good candidates for future research work $(1,8)$.

In Iranian Traditional Medicine, the noticeable roles of different plant families in the treatment of different illnesses are widely documented. In the recent review papers related to ethnobotanical studies published from 2004 to 2016, it was found that Labiatae was the most cited plant family (34 citations), that could be attributed to its broad distribution throughout Iran and multiple features of its plants (21). In the present work, it was found that Asteraceae is the second most reported plant family (33 citations) in Iranian Traditional Medicine. Other families including Fabaceae, Apiaceae, Brassiacaceae, Rosaceae and Solanaceae are also described. The most cited plant families in Iranian Traditional Medicine are as follows:

\section{Lamiaceae in Iran and its ethnomedicinal use}

The family contains ca. 241 genera and 7530 species/infraspecific taxa in the world (5). Family Lamiaceae comprises a wide diversity of chemical components particularly volatile oils, saponins, tannins, quinones and irodoids. Plants belonging to this family are commercially significant either for their uses as seasoning or their essential oils. The Lamiaceae (Labiatae) is one of the utmost important families of Iranian flora and its aromatic members including Lallemantia iberica (M.Bieb.) Fisch. \& C.A.Mey., Marrubium vulgare L., Melissa officinalis L., Mentha spp., Nepeta binaloudensis Jamzad, Ocimum basilicum L., Rosmarinus officinalis L., Salvia leriifolia Benth., Satureja hortensis L., Stachys lavandulifolia Vahl, Teucrium polium L., Vitex negundo L., Zataria multiflora Boiss. and Ziziphora clinopodioides Lam. are broadly employed in Iranian Traditional Medicine for the cure of respiratory problems, digestive disorders, urinary problems, metabolic disorders, abdominal complaints, inflammation and infections $(11,68,69)$.

\section{Ethnomedicinal use of Asteraceae in Iran}

The Asteraceae contains ca. 1623 genera and 24700 species/infraspecific taxa and is considered as the second largest family of vascular plants (after Orchidaceae ca. 736 genera, ca. 28000 species) in the world (5). Family Asteraceae has been known to produce a wide spectrum of secondary metabolites containing sesquiterpenes, lactones, saponins, coumarins, cyclitols and flavonols. Moreover, various kinds of alkaloids (pyridine, pyrrolizidine, quinoline, and diterpenoids) exist in this family. Asteraceae is also the second-largest plant family (after Fabaceae) in the flora of Iran, including many therapeutic and aromatic plants. Different taxa of this family such as Achillea santolinoides subsp. wilhelmsii (K.Koch) Greuter, Arctium lappa L., Artemisia spp., Calendula officinalis L., Carthamus tinctorius L., Cichorium intybus L., Helichrysum graveolens (M.Bieb) Sweet, Matricaria chamomilla L., and Silybum marianum (L.) Gaertn. are the most popular plants in Iranian folk medicine and are often used for the treatment of digestive illnesses, respiratory diseases, skin problems, neurological disorders, urinary problems, metabolic disorders, infections and inflammation (11, 21, 68).

\section{Ethnomedicinal use of Fabaceae (Leguminosae) in Iran}

This is the third major family of vascular plant in the world and contains ca. 751 genera and 19500 species/ infraspecific taxa (5). Among the chemical components, unusual aminoacids and tannins occur in the family, often with alkaloids and sometimes cyanogenic. The Fabaceae (Leguminosae) is the largest plant family in Iranian flora, including many medicinal plants. Various species of this family including Alhagi maurorum Medik., Astragalus spp., Cassia fistula L., Glycyrrhiza glabra L., Indigofera argentea Burm.f., Medicago sativa L., Securigera securidaca (L.) Degen \& Dorfl., Senna italica Mill. and Trigonella foenum-graecum L. are the most popular plants in Iranian traditional remedies and are often used for the cure of urinary disorders, gastrointestinal ailments, respiratory diseases and metabolic problems. Astragalus L. comprises of $c a$. 2900 annual and perennial species which is the largest genus in the plant kingdom and widely utilized as ornamental, medication, food and fuel ( 9 , 11, 21, 68).

\section{Ethnomedicinal use of Apiaceae (Umbelliferae) in Iran}

The family comprises of ca. 442 genera and 3575 species/infraspecific taxa in the world (5). Family Apiaceae comprises a broad diversity of chemical components particularly volatile oils, different types of coumarins, terpenes, triterpenoid resins and saponins acetylenic complexes. The Apiaceae is one of the biggest plant families in the flora of Iran, including many aromatic medicinal plants. Different species of this family including Anethum graveolens L., Apium graveolens L., Bunium persicum (Boiss.) B.Fedtsch., Coriandrum sativum L., Cuminum cyminum L., Dorema ammoniacum D.Don, Ferula spp., Ducrosia anethifolia (DC.) Boiss., Eryngium billardierei F.Delaroche, Falcaria vulgaris Bernh., Foeniculum vulgare Mill., Kelussia odoratissima Mozaff., Oliveria decumbens Vent., Petroselinum crispum (Mill.) Fuss, and Pimpinella anisum L. are very popular in Iranian folk medicine and are often used for the treatment of gastrointestinal problems, respiratory ailments, urinary complaints, skin disorders, wounds, infections and inflammation $(11,21,31,68)$.

\section{Ethnomedicinal use of Brassicaceae (Cruciferae) in Iran}

The family consists of ca. 328 genera and 3628 species/infraspecific taxa in the world (5). Several taxa of the family contain glucosinolates. Cardiac glycosides found in some genera and the seeds generally possess mucilage and fixed oil. Various species of Brassicaceae such as Alyssum alyssoides (L.) L., Anastatica hierochuntica L., Brassica nigra (L.) K.Koch, Capsella bursa-pastoris (L.) Medik., Descurainia sophia (L.) Webb ex Prantl, Eruca vesicaria (L.) Cav., Isatis raphanifolia Boiss., Lepidium sativum L. and Nasturtium officinale R.Br. are widely employed in Iranian Traditional Medicine, for the cure of respiratory disorders, gastritis, bronchitis, dermatitis and inflammation $(5,11,21,68)$. 


\section{Ethnomedicinal use of Iranian Rosaceae}

The family comprises of ca. 91 genera and 2950 species/infraspecific taxa in the world (5). Among the chemical components, sugar alcohols, terpenoids, tannins, cyanogenic glycosides, saponins, mucilage and cyclitols occur in this family. The Rosaceae is one of the main families of Iranian flora, including many medicinal plants. Different species of this family including Cotoneaster nummularius Fisch. \& C.A.Mey., Cydonia oblonga Mill., Rosa beggeriana Schrenk ex Fisch. \& C.A.Mey., Rosa $\times$ damascena Herrm. and Rosa foetida Herrm. are the most popular in Iranian folk medicine, and are often used for the treatment of digestive ailments, neurological complaints, urinary disorders and diabetes $(11,21$, $68)$.

\section{Ethnomedicinal use of Solanaceae in Iran}

The plant family contains $c a .100$ genera and 2600 species/infraspecific taxa in the world (5). Diverse alkaloids like indole, tropane, pyridine, purine, pyrazole etc. are found in this family. Anthraquinones, carotenoids, flavones, coumarins, withanolides, cyclitols and stroidal saponins are other types of alkaloids found in this family. Various species of this family such as Atropa belladonna L., Capsicum annuum L., Datura stramonium L., Hyoscyamus niger L., Physalis alkekengi L., Solanum americanum Mill., Withania coagulans (Stocks) Dunal and $W$. somnifera (L.) Dunal are very popular plants in Iranian folk medicine and are often used for the treatment of neurological illnesses, urinary disorders and abdominal complaints $(8,11,21,68)$.

\section{Ethnomedicinal use of Ferns, Mosses, Lichens and Mushrooms in Iran}

Very little information is available about ethnomedicinal aspects of ferns and mushrooms in Iran. In Iranian traditional medicine, two fern species including Adiantum capillus-veneris $\mathrm{L}$. (Pteridaceae) and Polypodium vulgare $\mathrm{L}$. (Polypodiaceae) are extensively applied in folklore medicine for the management of gastro-intestinal problems and respiratory ailments. The fruiting body of Laricifomes officinalis (Vill.) Kotl. \& Pouzar (Fomitopsidaceae) is known as Gharighun and Iranian Traditional Medicine practitioners recommends it as anti-hemorrhage and laxative (11, 26). No ethnobotanical documents could be recognized for the use of mosses and lichens in Iran.

It could be noted that there is still an absence of pharmacological and phytochemical studies on a lot of species of Iranian flora and additional trainings are needed to take further their medicinal prospects, which would serve as promising precursors for the progress and genesis of new plant based medicines in the future $(8,31)$.

Challenges for plants of Iranian Traditional Medicine system: Quality, safety and efficacy

Identification and authentication challenges of Iranian Traditional Medicine System

Medicinal herbs are still broadly applied in Iran and ITM has played a very significant role in providing healthcare of the population. In all cities and villages, people use medicinal plants according to their cultural background and this practical knowledge has been transmitted in different ways from generation to generation $(11,28)$. However, there are several challenges for medicinal plants and herbal medicines, particularly their identification and authentication in the country. In Iran, medicinal plants are generally referred to by their local or common names rather than scientific names $(8,41)$. Due to the history of Iran and its situation at the heart of the Silk Road that connected it with other countries, only vernacular names have been employed in the traditional literature related to Iranian ethnomedicine. It is too cumbersome to match such names with botanic names due to the immensely varied flora, language and diversity in the country. Local names are likely to cause obscurity as one plant species may have several vernacular names or one local name may be used for several different species. For instance, the popular name "Gol-e-babooneh" (in Persian), that is matched with Matricaria chamomilla L. (real babooneh) and six other species from Asteraceae (ie. Anthemis nobilis L., Anthemis wiedemanniana Fisch. \& C.A.Mey., Tripleurospermum disciforme (C.A.Mey.) Sch.Bip., Tanacetum parthenium (L.) Sch.Bip., T. persicum (Boiss.) Mozaff. and Microcephala lamellata (Bunge) Pobed.). Another example is "Avishan" (in Persian), that is employed for any of fourteen species of Thymus L. and one species of Zataria Boiss. in various parts of Iran (22, 41, 70, 71). Further to nomenclatural obscurity, the folk medicines sold in herbal markets in Iran are adulterated or exchanged with quite irrelevant plant substances. In general, adulteration is characterized as a practice of adding an external material from a different species to the authentic plant with an intention of enhancing the weight or strength of the product or to reduce its price. A national survey in Iran revealed that remarkable contributions of therapeutic plants existing in the herbal shops (Attari) are facing identification crisis along with adulteration and substitution problems. The Attaris have their own in house standards and mostly still practice organoleptic methods like taste, odour and touch to distinguish a medicinal plant which is considered unscientific. The spurious material may have different compounds than genuine medicinal plant that can cause health and safety concerns. To confirm safety and effectiveness of plant medicines, accurate documentation, validation and omission of adulteration are necessary and medicinal plant species must only be confirmed using a panel of specialists particularly experienced plant taxonomist (41). Moreover, it will be prudent to have dependable devices for differentiating genuine drugs from their adulterants. A wide range of methods can be used for identification and authentication of medicinal plants, including conventional morphology and phytochemistry based methods and modern molecular methods (72).

\section{Conventional approaches for medicinal plant authentication}

Conventionally, authentication and quality control depend mostly on morphological and phytochemical 
analyses, detailed in pharmacopoeias. In Iran, plant taxonomists tend to identify medicinal plants by macro and micro morphological methods. Micromorphological characterizations (botanical microscopy) is an exquisite method for authentication and quality assurance of herbal components as well as an inherent part of almost all pharmacopoeias $(19,73)$. In a recent study, the taxonomic evaluation of crude herbal drugs have shown a lot of misidentification, adulteration and substitution in the markets of Iran (see Table 3). In these herbal markets, some of the herbal drugs are misidentified, confused and adulterated with locally available herbal drugs. As can be seen in Table 3, Bunium cylindricum (Boiss. \& Hohen.) Drude (an adulterant) was admixed with Zire-siah (Bunium persicum (Boiss.) B.Fedtsch.) and sold in the herbal shops, which leads to deprivation of the value and efficacy of the original medicine. Adiantum capillusveneris $\mathrm{L}$. is commonly admixed with adulterants like Thalictrum sultanabadense Stapf (Ranunculaceae), owing to identical morphological characters or replaced by cheap materials in the market. Rheum provided workers with a range of new techniques for efficient and dependable identification of therapeutic plants. Among the popular genome-based approaches to dominate the complexity of traditional taxonomy, DNA barcoding has been found to be successful in the identification of plant species (76). Biomolecular procedures, like DNA barcoding and meta barcoding, have thus emerged as efficient ways for identification of plant ingredients in powder and complex herbal products. DNA barcoding can be applied for verifying produces based on components from different plants and DNA-meta barcoding for evaluation of components from different species or varieties from particular plant in treated produces (73). Even though this is an upward area of scientific attention, very little research has been done on the base of molecular techniques for authentication of medicinal plants in Iran $(71,77,78)$. In a recent study, the DNA barcoding of plant matter in herbal shops in Iran has shown a lot of adulteration and substitution. It was shown that 18 samples (26\%) of the therapeutic herbs sampled from the market were not having the species documented in the respective plant

Table 3. Some of the most common adulteration and substitution of crude drug in the different herbal markets of Iran (on the basis of macro- and micro-morphological methods).

\begin{tabular}{|c|c|c|c|c|c|}
\hline No. & Drug name & Authentic drug & Substituent/adulterants & Plant part used & References \\
\hline 1 & Afsantin & Artemisia absinthium L. & $\begin{array}{l}\text { Helichrysum graveolens (M.Bieb.) } \\
\text { Sweet }\end{array}$ & Flower & (41) \\
\hline 2 & Anjedane-roomi & Levisticum officinale W.D.J.Koch & Zosima absinthifolia Link & Fruit & (41) \\
\hline 3 & Barge-moord & Myrtus communis L. & Haplophyllum perforatum Kar. \& Kir. & Leaf & (39) \\
\hline 4 & Dome-asb & Equisetum arvense $\mathrm{L}$. & $\begin{array}{l}\text { Anabasis haussknechtii Bunge ex } \\
\text { Boiss. }\end{array}$ & Aerial parts & $(41)$ \\
\hline 5 & Eshghan & Rheum turkestanicum Janisch. & Rheum ribes L. & Root & $(41)$ \\
\hline 6 & Havachoobe & $\begin{array}{l}\text { Arnebia euchroma (Royle) } \\
\text { I.M.Johnst. }\end{array}$ & Onosma longilobum Bunge & Root & (41) \\
\hline 7 & Kakanaj & Physalis alkekengi L. & Hibiscus trionum L. & Flower & (41) \\
\hline 8 & Marzanjush & Origanum vulgare L. & Ziziphora clinopodioides Lam. & Aerial parts & $(41)$ \\
\hline 9 & Mokhallaseh & Scrophularia striata Boiss. & Tanacetum parthenium (L.) Sch. Bip. & Aerial parts & (8) \\
\hline 10 & Pare-siavashan & Adiantum capillus-veneris L. & Thalictrum sultanabadense Stapf & Aerial parts & $(41)$ \\
\hline & Zire-siah & Bunium persicum (Boiss.) B.Fedtsch. & $\begin{array}{l}\text { Bunium cylindricum (Boiss. \& Hohen.) } \\
\text { Drude }\end{array}$ & Fruit & (41) \\
\hline
\end{tabular}

turkestanicum Janisch. (Polygonaceae) is largely adulterated or substituted with Rheum ribes L. which can lead to the loss of its efficacy. Moreover, the replacement and adulteration of the medicinal plants can create safety and health issues (41).

Phytochemistry methods would serve as standard reference for correct identification of medicinal plant species but requires costly techniques, including X-ray, FTIR (Fourier-Transform Infrared Spectroscopy), HPLC (High Pressure Liquid Chromatography) NMR (Nuclear Magnetic Resonance), and TLC (Thin Layer Chromatography). Moreover, phytochemistry methods have limitations derived from the intricacy of investigation segmentation or powdered materials do not let comprehensive identification of the material $(74,75)$.

\section{Modern approaches for medicinal plant authentication}

Whereas differentiating power of structural and biochemical methods for species identification have limitations, molecular approaches are far more efficient, accurate and dependable (75). In recent years, progresses in the molecular genetics have pharmacopeia. The species intended for therapeutic usage, as recognized by the plant pharmacopeia, are adulterated locally with other species from the same genus or different species altogether. Commercial medicinal plants like Marzeh and Maryam goli were some instances, where DNA barcoding revealed that Urtica dioica L. (Urticaceae) was being sold instead of Satureja laxiflora K.Koch and Satureja hortensis L. (Marzeh) and also Althaea cannabina L. (Malvaceae) was replaced or admixed with Salvia officinalis L. (Maryam goli) (71). Therefore, the implementation of such methods for the confirmation of medicinal plants will warrant top quality plant based therapeutic produces, devoid of adulterants and lacking side effects that would have marked influence on the health of the consumers.

\section{Challenges of collection, drying and storage of medicinal plants}

In Iran, there is a general belief amongst the consumers of medicinal plants, that herbal drugs are always safe due to their natural origin and long history of traditional uses, but the lack of regulation of Iranian medicinal plants and inappropriate 
methods of gathering, drying and storage establishes no such assurance.

Collection of medicinal plants is the first step of phytochemical or related investigations and is one of the most important concerns for its quality. Medicinal plants gathered from the natural could be mixed with additional species or plant segments via mistaken identification. Poisoning from folk medicines is mostly as a result of wrong identification. For example, due to some morphological similarities, Anabasis haussknechtii Bunge ex Boiss. (Amaranthaceae) is mistakenly sold as Equisetum arvense L. (Equisetaceae) which may result in adverse effects and toxic effects $(41,79,80)$. Therefore, scientific identification and provision of voucher specimens are essential which can reduce such errors and support researchers with an improved understanding of their topics and relatively efficient investigation of their properties (9). Furthermore, collection of medicinal plants can be influenced by several factors, for instance, physiological (the age of the plant) and environmental (eg. sunlight, temperature, rainfall, soil features and height above sea level). This is necessary for the determination of reproducible outline of plant metabolites. Another major concern that remains is drying conditions of medicinal plants in Iran. Inadequate drying may result in mould growth and microbial fermentation, which can lead to the degradation of plant products $(80,81)$.

Concerns have also been raised regarding methods of storage of medicinal plants and produces in Iran. Recent studies on Iranian herbal water (plant water) revealed that its oral use and even vapour coverage is seriously poisonous for humans due to the presence of methanol and a low standard of processing for the duration of fabrication or storage of such plant waters through the fallouts of enzymes on pectins in the cell wall. The existence of more wooden structures in a plant could make it more sensitive to methanol fabrication. Therefore, if the woody organ of a plant is reduced to the maximum probability and direct vapour distillation is employed for the period of fabrication causing lesser enzyme property, methanol concentration will be much lesser in the final output $(82,83)$. Thus, the processing stages from sorting of medicinal plants to the distillation, needs to be modified in order to diminish methanol concentrations. Moreover, comprehensive investigation and the standardization are indispensable to regulate the quality of raw herbal medicines and to authenticate their usages in the up to date health care schemes.

\section{Challenges of poisonous plants used in traditional medicine}

Undoubtedly the demand for plant based remedies is greater than before globally. Keeping this in view, the efficacy of herbal medicine needs improvement in terms of their quality and safety. Plant kingdom possess many secondary metabolites, and thus some plants are very poisonous. Herbal therapy in other complementary usage carries a higher potential of adverse effects, hazards and toxicity $(47,84)$. Among secondary metabolites, pyrrolizidine alkaloids are very dangerous and are synthesized in almost all species of Boraginaceae and in a number of species of Asteraceae (subfamily Senecioninae) and Fabaceae (tribe Crotalarieae). Activation of these compounds in liver of animal/human causes production of dehydropyrrolizidines as a reactive pyrroles which finally formed alkylated DNA bases. These DNA alkylations can result in mutation and cell dying (particularly in liver). Moreover, mutations can result in abnormalities in pregnant animals/humans and in the cancer of liver, kidneys and lungs. Several pyrrolizidine alkaloids comprising plants are employed in folk phyto medicine to remedy bloodshed or diabetes and common as herbal tea (Crotalaria L., Heliotropium L., Petasites Mill., Senecio L.); Symphytum officinale L. (Boraginaceae) and other Boraginaceae species to remedy wounds and broken or damaged bones. Others, such as Symphytum $\mathrm{x}$ uplandicum Nyman are commonly provided on local herbal shops as "healthy" salad components. It should be noted that plants containing pyrrolizidine alkaloids should be avoided and are banned as medicines (85).

Toxicity by traditional plant based therapies in Iran is not scarce. Several medicinal plants with a long history of folk usage are suspected to be carcinogenic and/or hepatotoxic. For example, recent studies reported hepatotoxicity cases due to inappropriate consumption of Echium amoenum Fisch. \& C.A.Mey. (Gole-Gavzaban) (Boraginaceae) as a famous herbal medicine in Iran, resulting in hepatic failure and hospital admission $(86,87)$. The most important Iranian traditional medicinal plant species that can pose critical threat to the health of humans are presented in Table 4 and images of few of them are shown in Fig. 2.

\section{Challenges of conservation of Iranian medicinal plants}

One of the most important challenges for medicinal plants is the loss of endemic, rare and narrow-range taxa, because of the non-principled use, mismanagement and overexploitation. Many species of endemic medicinal plants of Iran are harshly threatened in the wild and are severely harvested consequently, are now endangered. Iran has a unique habitat due to its biodiversity and endemism of a number of plant species. The concept of endemism and the proportion of endemic species to the total number of species is very important in biodiversity and conservation biology $(1,8)$.

The Iranian vascular flora encompasses a total of 2597 endemic or sub-endemic species. The IranoTuranian phytochoria harbours $88 \%$ of the Iranian endemics. There are no endemic families, but 26 endemic and sub-endemic genera. Dicots include 2421 endemic taxa in Iran, monocots contain 175 endemics and gymnosperms have only one (1). Lamiaceae is a noteworthy medicinal family in the Iran flora with 155 endemic taxa. The other important medicinal families in this category are Apiaceae with 127, Brassicaceae with 88, Fabaceae with 687 and Asteraceae with 618 endemic taxa. Several endemic species of these medicinal families 
Table 4. Some of the most important poisonous plants used in folklore medicine of Iran.

\begin{tabular}{|c|c|c|c|c|c|c|c|}
\hline No. & $\begin{array}{l}\text { Drug name } \\
\& \text { part used }\end{array}$ & $\begin{array}{l}\text { Scientific } \\
\text { name }\end{array}$ & Family & $\begin{array}{l}\text { Ethnomedicinal } \\
\text { uses }\end{array}$ & $\begin{array}{l}\text { Toxic } \\
\text { substance }\end{array}$ & Side effects/ Modes of action & References \\
\hline 1 & $\begin{array}{l}\text { Agir Torki } \\
\text { (Root) }\end{array}$ & $\begin{array}{l}\text { Acorus } \\
\text { calamus L. }\end{array}$ & Acoraceae & $\begin{array}{l}\text { Treatment of } \\
\text { Urinary } \\
\text { incontinence, } \\
\text { diuretic, } \\
\text { carminative, } \\
\text { stimulant, } \\
\text { hematinic }\end{array}$ & $\begin{array}{l}\text { Phenylpropanoi } \\
\text { ds } \\
\text { (asarone) }\end{array}$ & $\begin{array}{l}\text { It is converted to epoxides in the } \\
\text { liver, which can alkylate } \\
\text { proteins and DNA (resulting in } \\
\text { mutation and tumour) }\end{array}$ & $(11,85)$ \\
\hline 2 & $\begin{array}{l}\text { Shokaran } \\
\text { (Root) }\end{array}$ & $\begin{array}{l}\text { Conium } \\
\text { maculatum L. }\end{array}$ & Apiaceae & $\begin{array}{l}\text { Cholagogue, } \\
\text { depilator, } \\
\text { treatment of } \\
\text { dermal allergies }\end{array}$ & $\begin{array}{l}\text { Piperidine } \\
\text { Alkaloids }\end{array}$ & Extremely toxic and teratogenic & $(11,85)$ \\
\hline 3 & $\begin{array}{l}\text { Zaravand } \\
\text { (Root) }\end{array}$ & $\begin{array}{l}\text { Aristolochia } \\
\text { rotunda L. }\end{array}$ & $\begin{array}{l}\text { Aristolochiacea } \\
\mathrm{e}\end{array}$ & $\begin{array}{l}\text { Emmenagogue, } \\
\text { diuretic, anti- } \\
\text { atherosclerosis, } \\
\text { tonic, treatment of } \\
\text { rheumatism }\end{array}$ & $\begin{array}{l}\text { Aristolochic } \\
\text { acids }\end{array}$ & $\begin{array}{l}\text { It causes DNA alkylations, which } \\
\text { can cause mutation and after } \\
\text { long-term use, cancer (especially } \\
\text { in the liver) }\end{array}$ & $(11,85)$ \\
\hline 4 & $\begin{array}{l}\text { Asarun } \\
\text { (Root) }\end{array}$ & $\begin{array}{l}\text { Asarum } \\
\text { europaeum L. }\end{array}$ & $\begin{array}{l}\text { Aristolochiacea } \\
\mathrm{e}\end{array}$ & Tonic, stimulant & $\begin{array}{l}\text { Phenylpropanoi } \\
\text { ds } \\
\text { (asarone) }\end{array}$ & $\begin{array}{l}\text { It is converted to epoxides in the } \\
\text { liver, which can alkylate } \\
\text { proteins and DNA (resulting in } \\
\text { mutation and tumour) }\end{array}$ & $(11,85)$ \\
\hline 5 & $\begin{array}{l}\text { Onsol, Gaav } \\
\text { Piazi (Bulb) }\end{array}$ & $\begin{array}{l}\text { Drimia } \\
\text { maritima (L.) } \\
\text { Stearn (Syn. } \\
\text { Urginea } \\
\text { maritima (L.) } \\
\text { Baker) }\end{array}$ & Asparagaceae & $\begin{array}{l}\text { Emmenagogue, } \\
\text { hair } \\
\text { tonic, toothache, } \\
\text { kidney stones, } \\
\text { rheumatism, joint } \\
\text { pains }\end{array}$ & $\begin{array}{l}\text { Cardiac } \\
\text { Glycosides }\end{array}$ & $\begin{array}{l}\text { Strong neurotoxin, which causes } \\
\text { death through cardiac and } \\
\text { respiratory arrest (inhibits } \\
\mathrm{Na}^{+}, \mathrm{K}+- \text { ATPase) }\end{array}$ & $(11,85)$ \\
\hline 6 & $\begin{array}{l}\text { Bumadaran } \\
\text { (Aerial parts) }\end{array}$ & Achillea spp. & Asteraceae & $\begin{array}{l}\text { Treatment of } \\
\text { gastrointestinal } \\
\text { diseases, treatment } \\
\text { of osteoarthritis, } \\
\text { blood flooding, } \\
\text { hypoglycemic, } \\
\text { nerve tonic }\end{array}$ & Thujone & $\begin{array}{l}\text { Thujone can alkylate important } \\
\text { proteins of the neuronal signal } \\
\text { transduction, therefore causing } \\
\text { neuronal disorder }\end{array}$ & $(11,85)$ \\
\hline 7 & $\begin{array}{l}\text { Afsantin } \\
\text { (Aerial parts) }\end{array}$ & $\begin{array}{l}\text { Artemisia } \\
\text { absinthium L. }\end{array}$ & Asteraceae & $\begin{array}{l}\text { Anthelmintic, } \\
\text { appetizer, } \\
\text { indigestion }\end{array}$ & Thujone & $\begin{array}{l}\text { Thujone can alkylate important } \\
\text { proteins of the neuronal signal } \\
\text { transduction, therefore causing } \\
\text { neuronal disorder }\end{array}$ & $(11,85)$ \\
\hline 8 & $\begin{array}{l}\text { Pa Khari } \\
\text { (Aerial parts) }\end{array}$ & $\begin{array}{l}\text { Tussilago } \\
\text { farfara } \mathrm{L} .\end{array}$ & Asteraceae & $\begin{array}{l}\text { Expectorant, } \\
\text { antitussive, mouth } \\
\text { wounds, treatment } \\
\text { of furuncles }\end{array}$ & $\begin{array}{l}\text { Pyrrolizidine } \\
\text { Alkaloids }\end{array}$ & $\begin{array}{l}\text { It causes DNA alkylations, which } \\
\text { can cause mutation and after } \\
\text { long-term use, cancer (especially } \\
\text { in the liver) }\end{array}$ & $(11,85)$ \\
\hline 9 & $\begin{array}{l}\text { Gole } \\
\text { gavzabane } \\
\text { pirzani } \\
\text { (Flower) }\end{array}$ & $\begin{array}{l}\text { Anchusa } \\
\text { aegyptiaca (L.) } \\
\text { A.DC. }\end{array}$ & Boraginaceae & $\begin{array}{l}\text { Skin dermatitis, } \\
\text { herpes }\end{array}$ & $\begin{array}{l}\text { Pyrrolizidine } \\
\text { Alkaloids }\end{array}$ & $\begin{array}{l}\text { DNA alkylations can cause } \\
\text { mutation and after long-term } \\
\text { use, cancer (especially in the } \\
\text { liver) }\end{array}$ & $(85,102)$ \\
\hline 10 & $\begin{array}{l}\text { Gul-guzan, } \\
\text { Gole gaav } \\
\text { Zaban } \\
\text { (Flower) }\end{array}$ & $\begin{array}{l}\text { Anchusa } \\
\text { azurea Mill. } \\
\text { (Syn. A. italica } \\
\text { Retz.) }\end{array}$ & Boraginaceae & $\begin{array}{l}\text { Cold, sedative, } \\
\text { influenza }\end{array}$ & $\begin{array}{l}\text { Pyrrolizidine } \\
\text { Alkaloids }\end{array}$ & $\begin{array}{l}\text { DNA alkylations can cause } \\
\text { mutation and after long-term } \\
\text { use, cancer (especially in the } \\
\text { liver) }\end{array}$ & $(26,85,102)$ \\
\hline 11 & $\begin{array}{l}\text { Havachoobeh } \\
\text { (Root) }\end{array}$ & $\begin{array}{l}\text { Arnebia } \\
\text { euchroma } \\
\text { (Royle) } \\
\text { I.M.Johnst. }\end{array}$ & Boraginaceae & $\begin{array}{l}\text { Treatment of } \\
\text { dermal disorders, } \\
\text { hair } \\
\text { tonic }\end{array}$ & $\begin{array}{l}\text { Pyrrolizidine } \\
\text { Alkaloids }\end{array}$ & $\begin{array}{l}\text { DNA alkylations can cause } \\
\text { mutation and after long-term } \\
\text { use, cancer (especially in the } \\
\text { liver) }\end{array}$ & $(11,85)$ \\
\hline 12 & $\begin{array}{l}\text { Gavzaban } \\
\text { sabz (Aerial } \\
\text { parts) }\end{array}$ & $\begin{array}{l}\text { Caccinia } \\
\text { macranthera } \\
\text { (Banks \& Sol.) } \\
\text { Brand }\end{array}$ & Boraginaceae & $\begin{array}{l}\text { Sedative, } \\
\text { treatment of } \\
\text { cough, expectorant }\end{array}$ & $\begin{array}{l}\text { Pyrrolizidine } \\
\text { Alkaloids }\end{array}$ & $\begin{array}{l}\text { DNA alkylations can cause } \\
\text { mutation and after long-term } \\
\text { use, cancer (especially in the } \\
\text { liver) }\end{array}$ & $(11,85)$ \\
\hline 13 & $\begin{array}{l}\text { Gole } \\
\text { Gavzaban } \\
\text { (Flower) }\end{array}$ & $\begin{array}{l}\text { Echium } \\
\text { amoenum } \\
\text { Fisch. \& } \\
\text { C.A.Mey. }\end{array}$ & Boraginaceae & $\begin{array}{l}\text { Antihypertensive, } \\
\text { nerve tonic, } \\
\text { diuretic, antistress, } \\
\text { blood cleanser, } \\
\text { cardiac tonic }\end{array}$ & $\begin{array}{l}\text { Pyrrolizidine } \\
\text { Alkaloids }\end{array}$ & $\begin{array}{l}\text { DNA alkylations can cause } \\
\text { mutation and after long-term } \\
\text { use, cancer (especially in the } \\
\text { liver) }\end{array}$ & $(11,85)$ \\
\hline 14 & Kalak (leaf) & $\begin{array}{l}\text { Heliotropium } \\
\text { dasycarpum } \\
\text { Ledeb. ex. } \\
\text { Eichw. }\end{array}$ & Boraginaceae & Itching & $\begin{array}{l}\text { Pyrrolizidine } \\
\text { Alkaloids }\end{array}$ & $\begin{array}{l}\text { DNA alkylations can cause } \\
\text { mutation and after long-term } \\
\text { use, cancer (especially in the } \\
\text { liver) }\end{array}$ & $(22,85)$ \\
\hline 15 & Kalak (leaf) & $\begin{array}{l}\text { Heliotropium } \\
\text { europaeum L. }\end{array}$ & Boraginaceae & Itching & $\begin{array}{l}\text { Pyrrolizidine } \\
\text { Alkaloids }\end{array}$ & $\begin{array}{l}\text { DNA alkylations can cause } \\
\text { mutation and after long-term } \\
\text { use, cancer (especially in the } \\
\text { liver) }\end{array}$ & $(22,85)$ \\
\hline 16 & $\begin{array}{l}\text { Alaf-esimkesh } \\
\text { (Aerial parts) }\end{array}$ & $\begin{array}{l}\text { Trichodesma } \\
\text { incanum } \\
\text { (Bunge) A.DC. }\end{array}$ & Boraginaceae & $\begin{array}{l}\text { Treatment of bone } \\
\text { fracture }\end{array}$ & $\begin{array}{l}\text { Pyrrolizidine } \\
\text { Alkaloids }\end{array}$ & $\begin{array}{l}\text { DNA alkylations can cause } \\
\text { mutation and after long-term } \\
\text { use, cancer (especially in the } \\
\text { liver) }\end{array}$ & $(11,85)$ \\
\hline 17 & $\begin{array}{l}\text { Zabun Gueri } \\
\text { (Seed) }\end{array}$ & $\begin{array}{l}\text { Rindera lanata } \\
\text { Bunge }\end{array}$ & Boraginaceae & Joint pains & $\begin{array}{l}\text { Pyrrolizidine } \\
\text { Alkaloids }\end{array}$ & $\begin{array}{l}\text { DNA alkylations can cause } \\
\text { mutation and after long-term use, } \\
\text { cancer (especially in the liver) }\end{array}$ & $(85,102)$ \\
\hline
\end{tabular}




\begin{tabular}{|c|c|c|c|c|c|c|c|}
\hline 18 & $\begin{array}{l}\text { Hanzal } \\
\text { (Fruit-Seed) }\end{array}$ & $\begin{array}{l}\text { Citrullus } \\
\text { colocynthis } \\
\text { (L.) } \\
\text { Schrad. }\end{array}$ & Cucurbitaceae & $\begin{array}{l}\text { Purgative, } \\
\text { anodyne, } \\
\text { hypoglycemic }\end{array}$ & $\begin{array}{l}\text { Anthraquinone } \\
\mathrm{s}\end{array}$ & $\begin{array}{l}\text { Anthraquinones can intercalate } \\
\text { DNA long-term usage }\end{array}$ & $(11,85)$ \\
\hline 19 & $\begin{array}{l}\text { Karchak } \\
\text { (Seed) }\end{array}$ & $\begin{array}{l}\text { Ricinus } \\
\text { communis L. }\end{array}$ & Euphorbiaceae & Purgative & Lectins (ricin) & \multirow[b]{2}{*}{$\begin{array}{l}\text { Lectins are toxic when taken } \\
\text { orally and bind to cells via the } \\
\text { haptomer and become } \\
\text { internalized by endocytosis. } \\
\text { Once in the cell they have an } \\
\text { affinity for ribosomes and the A- } \\
\text { chain (the effectomer, which has } \\
\text { N-glycosidase activity) blocks } \\
\text { ribosomal protein translation by } \\
\text { inactivating elongation factors } \\
\text { EF1 and EF2. A cell that no } \\
\text { longer is able to make proteins } \\
\text { will die. }\end{array}$} & $(11,85)$ \\
\hline 20 & $\begin{array}{l}\text { Cheshm } \\
\text { Khorus (Seed) }\end{array}$ & $\begin{array}{l}\text { Abrus } \\
\text { precatorius L. }\end{array}$ & Fabaceae & Contraceptive & Lectins (abrin) & & $(11,85)$ \\
\hline 21 & $\begin{array}{l}\text { Kachuleh } \\
\text { (Seed) }\end{array}$ & $\begin{array}{l}\text { Strychnos } \\
\text { nux-vomica L. }\end{array}$ & Loganiaceae & $\begin{array}{l}\text { Antiallergic, } \\
\text { eczema, sedative }\end{array}$ & $\begin{array}{l}\text { Indole } \\
\text { Alkaloids }\end{array}$ & Neuromuscular blocking agents & $(11,85)$ \\
\hline 22 & $\begin{array}{l}\text { Joze Buya } \\
\text { (Seed) }\end{array}$ & $\begin{array}{l}\text { Myristica } \\
\text { fragrans } \\
\text { Houtt. }\end{array}$ & Myristicaceae & $\begin{array}{l}\text { Treatment of } \\
\text { gastrointestinal } \\
\text { diseases }\end{array}$ & $\begin{array}{l}\text { Phenylpropanoi } \\
\text { ds (myristicin) }\end{array}$ & $\begin{array}{l}\text { Myristicin is converted to } \\
\text { epoxides in the liver, which can } \\
\text { alkylate proteins and DNA } \\
\text { (resulting in mutation and } \\
\text { tumour) }\end{array}$ & $(11,85)$ \\
\hline 23 & $\begin{array}{l}\text { Gol } \\
\text { Angoshtaneh } \\
\text { (Flower) }\end{array}$ & $\begin{array}{l}\text { Digitalis } \\
\text { purpurea L. }\end{array}$ & Plantaginaceae & Cardiac tonic & $\begin{array}{l}\text { Cardiac } \\
\text { Glycosides }\end{array}$ & $\begin{array}{l}\text { Strong neurotoxin, which causes } \\
\text { death through cardiac and } \\
\text { respiratory arrest (inhibits } \\
\left.\mathrm{Na}^{+}, \mathrm{K}+-\mathrm{ATPase}\right)\end{array}$ & $(11,85)$ \\
\hline
\end{tabular}

are frequently used in Iranian Traditional Medicine. Zhumeria majdae Rech.f. \& Wendelbo (Lamiaceae) and Nepeta binaloudensis Jamzad are important endemic medicinal plants, which have been severely harvested and are now endangered with narrow distribution and low abundance. Nepeta binaloudensis is commonly known as "Ostokhodus", has been recommended to cure pulmonary infections, rheumatism and as antiasthmatic, antitussive and cardiac tonic. Ribes khorasanicum Saghafi \& Assadi (Grossulariaceae) is another endemic species with a small distribution range in Iran which is exposed to heavy usage by inhabitants of the area. Because of overharvesting, these species are calling a wake-up alarm for conservation (1, 11, 88). Ferula latisecta Rech.f. \& Aellen and Dorema
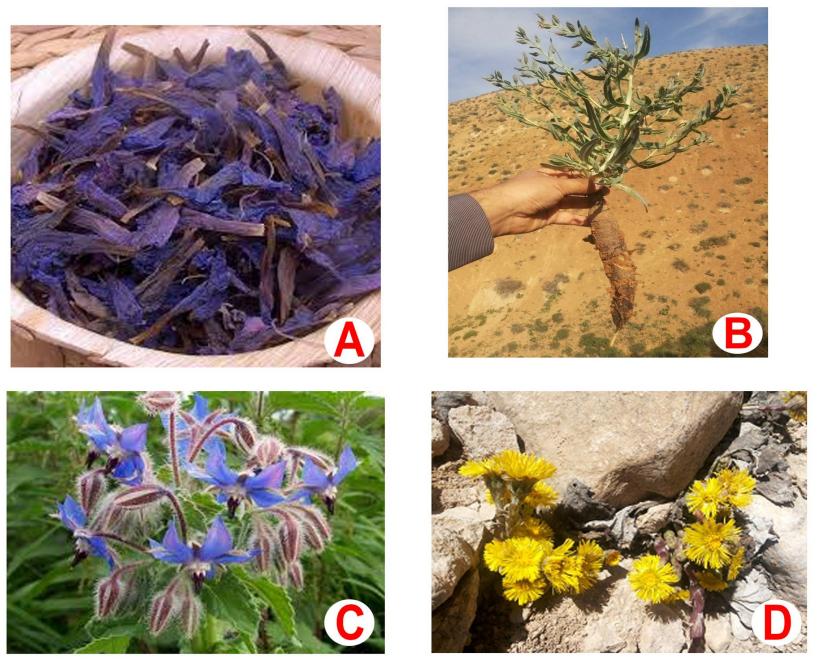

Fig. 2. Some of the most important traditional medicinal plants contaning pyrrolizidine alkaloids in the markets of Iran: (A) Echium amoenum Fisch. \& C.A.Mey., a popular poisonous plant used in folklore medicine of Iran; (B) Caccinia macranthera (Banks \& Soland.) Brand, a poisonous species occur in the bazaars of Iran; (C) Borago officinalis L., a poisonous plant occur in some bazaars of Iran; (D) Tussilago farfara L., a poisonous species found in the markets of Iran kopetdaghense Pimenov are endangered medicinal plants belonging to Apiaceae family. Continued overutilization and habitat degradation of these invaluable species for therapeutic and food purposes may lead to the eradication from the area. Zataria multiflora Boiss. is another medicinal plant in Iran, known from ancient times, is also severely harvested and because of its low reproduction, it should be considered in conservation management programmes. There are also concerns around some other medicinal species such as Dorema aucheri Boiss., Echinophora cinerea (Boiss.) Hedge \& Lamond (Apiaceae), Ferula hezarlalehzarica Ajani, Heracleum gorganicum Rech.f. and Kelussia odoratissima Mozaff. which are constricted range endemics and found just in a few particular niches $(30,31,88,89)$. Some of the important endangered medicinal plant species of Iran are illustrated in Table 5 and are shown in Fig. 3. Diverse applications of traditional medicine, continued collection from wild populations and destructive harvesting approaches, particularly elimination of subterranean part will inevitably result in decrease in populations, loss of genetic diversity and local extinctions of these invaluable taxa and it alarms for an impending disaster.

Unfortunately, the continuous and enhancing anthropogenic pressures containing deforestation, inappropriate overgrazing, amplification of agriculture, drainage of wetlands, industrialized development, road construction and plant material overexploitation as a source of income for native poor people, have already influenced the growth, endurance and distribution of native species in Iran, particularly the rare and endemic species $(31,88,89)$. Therefore, there is a strong need to develop conservation strategies for better protection of all common endemic medicinal plant species assigned to a threat category. To achieve this, different sets of modalities have been recommended, such as providing both in-situ conservation (natural reserves and wild nurseries) and ex-situ conservation (botanic 
Table 5. List of the most important threatened medicinal plant species of Iran.

\begin{tabular}{|c|c|c|c|c|c|}
\hline No. & Family & Species/infraspecific taxa & $\begin{array}{l}\text { Red list } \\
\text { categories } \\
\text { and criteria } \\
\end{array}$ & Ethnobotanical uses & References \\
\hline 1 & Amaryllidaceae & $\begin{array}{l}\text { Allium stipitatum Regel (Syn. } A . \\
\text { hirtifolium Boiss.) }\end{array}$ & EN & Used as a spice within foods & (88) \\
\hline 2 & Amaryllidaceae & Allium ellisii Hook.f. & VU & Used as a spice within foods & $(88,89)$ \\
\hline 3 & Apiaceae & Dorema ammoniacum D.Don & LR & $\begin{array}{l}\text { Treatment of gastrointestinal and respiratory } \\
\text { problems }\end{array}$ & $(31,88)$ \\
\hline 4 & Apiaceae & Dorema aucheri Boiss. & LR & $\begin{array}{l}\text { Treatment of gastrointestinal and respiratory } \\
\text { diseases, burn healing }\end{array}$ & $(31,88)$ \\
\hline 5 & Apiaceae & $\begin{array}{l}\text { Echinophora cinerea (Boiss.) } \\
\text { Hedge \& Lamond }\end{array}$ & LR & $\begin{array}{l}\text { Stimulant and an invigorator of the stomach, } \\
\text { diuretic, anti-cancer }\end{array}$ & $(31,88)$ \\
\hline 6 & Apiaceae & Echinophora platyloba DC. & LR & $\begin{array}{l}\text { Dissolves renal calculi, anti aphthous (mouth } \\
\text { wash), antifungal }\end{array}$ & $(31,88)$ \\
\hline 7 & Apiaceae & Ferula assa-foetida L. & EN & $\begin{array}{l}\text { Treatment of gastrointestinal and respiratory } \\
\text { problems }\end{array}$ & $(31,88)$ \\
\hline 8 & Apiaceae & Ferula latisecta Rech.f. \& Aellen & EN & Indigestion and anthelmintic & $(31,89)$ \\
\hline 9 & Apiaceae & Ferula macrocolea Boiss. & LR & Anti-nausea, anti-stomach acid & $(88,103$ \\
\hline 10 & Apiaceae & $\begin{array}{l}\text { Ferulago angulata subsp. } \\
\text { carduchorum (Boiss. \& Hausskn.) } \\
\text { D.F.Chamb. (Syn. F. carduchorum } \\
\text { Boiss. \& Hausskn.) }\end{array}$ & LR & Dermal wounds & $(29,88)$ \\
\hline 11 & Apiaceae & Haussknechtia elymaitica Boiss. & VU & Diabetes, hypertension & $(88,102)$ \\
\hline 12 & Apiaceae & Heracleum gorganicum Rech.f. & LR & Flavoring, digestive disorders & $(26,88)$ \\
\hline 13 & Apiaceae & Kelussia odoratissima Mozaff. & EN & $\begin{array}{l}\text { Treatment of gastrointestinal and respiratory } \\
\text { diseases, sedative, hypertension, } \\
\text { cardiovascular diseases, inflammation ulcers }\end{array}$ & $(31,104)$ \\
\hline 14 & Apiaceae & Prangos cheilanthifolia Boiss. & LR & Treatment of flatulency & $(57,88)$ \\
\hline 15 & Apiaceae & Psammogeton canescens Vatke & LR & Disinfectants & $(27,88)$ \\
\hline 16 & Asparagaceae & Danae racemosa (L.) Moench & EN & Fruits are used for dying silk & $(26,88)$ \\
\hline 17 & Grossulariaceae & $\begin{array}{l}\text { Ribes khorasanicum Saghafi \& } \\
\text { Assadi }\end{array}$ & EN & Antihypertensive, diabetes, depurative & $(11,89)$ \\
\hline 18 & Lamiaceae & Dracocephalum kotschyi Boiss & EN & Fever, analgesic, rheumatism & $(88,105)$ \\
\hline 19 & Lamiaceae & Nepeta binaloudensis Jamzad & EN & $\begin{array}{l}\text { Treatment of gastrointestinal and respiratory } \\
\text { diseases, treatment of rheumatism, cardiac } \\
\text { tonic }\end{array}$ & $(11,89)$ \\
\hline 20 & Lamiaceae & Satureja bachtiarica Bunge & LR & Flatulence, edible & $23,88)$ \\
\hline 21 & Lamiaceae & Satureja khuzistanica Jamzad & VU & $\begin{array}{l}\text { Inflammation, toothache, common cold, } \\
\text { antiseptic, analgesic }\end{array}$ & $(88,105)$ \\
\hline 22 & Lamiaceae & Thymus daenensis Celak. & LR & $\begin{array}{l}\text { Fever, diuretic, vermifuge, flatulence, } \\
\text { appetizer, toothache }\end{array}$ & $(88,105)$ \\
\hline 23 & Lamiaceae & Zataria multiflora Boiss. & LR & $\begin{array}{l}\text { Treatment of gastrointestinal and respiratory } \\
\text { diseases, menstrual pains, dysmenorrheal, } \\
\text { anthelmintic }\end{array}$ & $(11,88)$ \\
\hline 24 & Lamiaceae & $\begin{array}{l}\text { Zhumeria majdae Rech.f. \& } \\
\text { Wendelbo }\end{array}$ & EN & $\begin{array}{l}\text { Stomachache, antiseptic, painful } \\
\text { menstruation }\end{array}$ & $(88,105,106)$ \\
\hline 25 & Liliaceae & Fritillaria imperialis L. & EN & Treatment of joints pain & $(11,107)$ \\
\hline
\end{tabular}

gardens and seed banks). Moreover, resource management (eg. good agricultural practices and sustainable use solutions) and biotechnological methods (eg. cell culture, micropropagation, artificial seed technology and molecular marker-based methodologies) should be effectively taken into account for the sustainable use and improved yield of medicinal plants. Enhanced cultivation contributes to reduction in the harvest volume of medicinal plants that can lead to the recovery of their wild resources (90).

\section{Conclusion and future prospects}

The growing global demand for plant based remedies has necessitated attention to increased concerns over different aspects of source plant material that constitutes the medicine. In Iran, plant based drugs are facing challenges of authenticity, quality, safety and efficacy.
Currently, there are no standards for identification and confirmation of medicinal plants and herbal products in Iran. Microscopy has been employed to identify herbal products in Iran that has shown a lot of adulteration and substitution in the herbal markets. Microscopic authentication is a fast and cost efficient method, but it has restricted applicability for powdered and mixtures samples. The use of molecular markers as analytic techniques and DNA barcoding or meta barcoding are proposed for the correct identification of medicinal plant species used in Iran and authenticated plant products.

Many medicinal plant species are sensitive to climatic situations, requiring appropriate drying and storage under controlled temperature and humidity. Improper approaches of collection, drying and storage with adverse pollutants (eg. pesticides, heavy metals, microbial pollutants, toxic plants and adulterants) in the products, have all contributed to the undesirable impact with regards to Iranian 

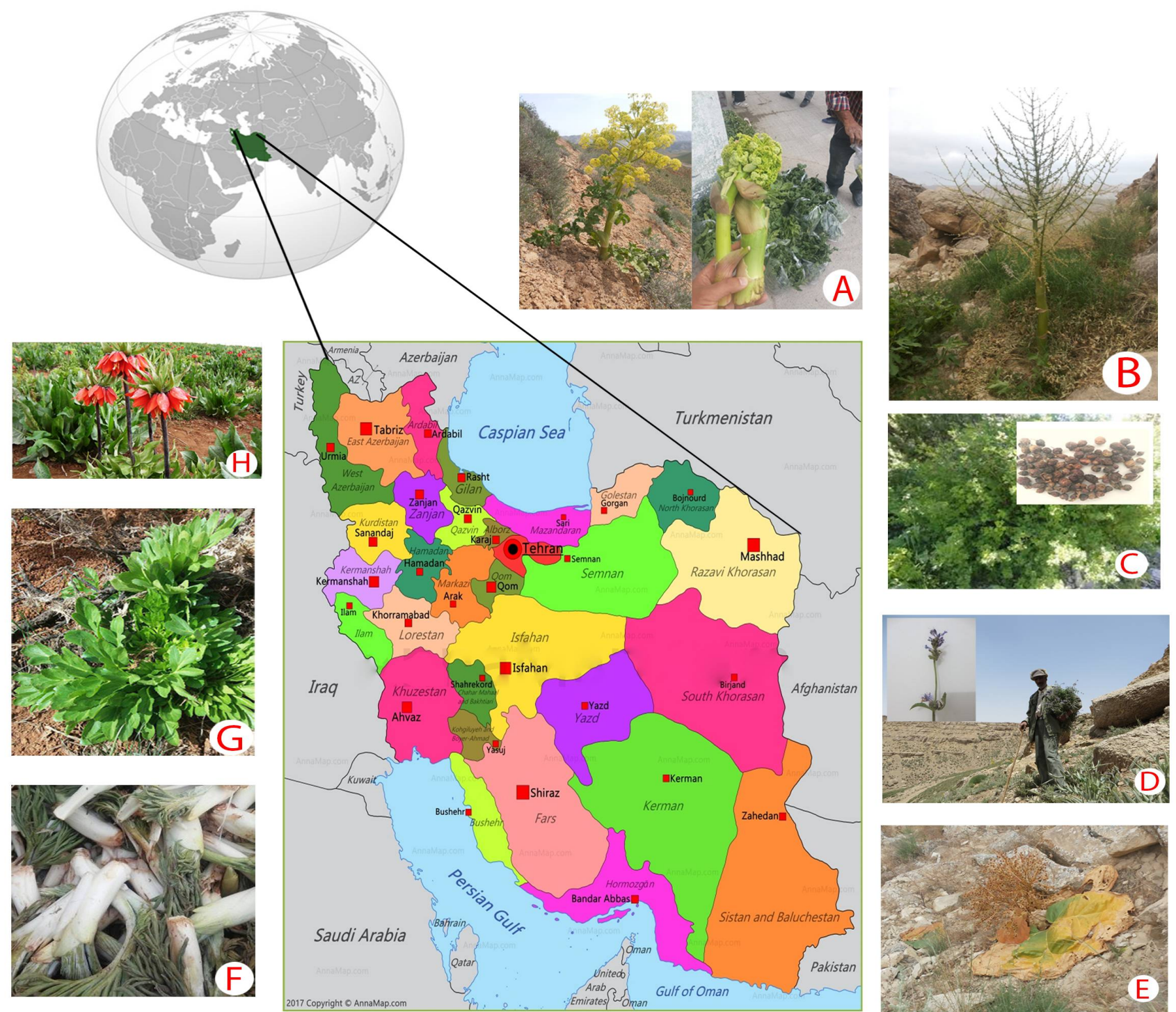

Fig. 3. Selected rare and endangered medicinal plants of Iran: (A) Ferula latisecta Rech.f. \& Aellen, an endangered medicinal species occurs in NE of Iran; (B) Dorema kopetdaghense Pimenov, an endangered medicinal plant found in NE of Iran; (C) Ribes khorasanicum Saghafi \& Assadi, an endangered medicinal species occurs in a small area in NE of Iran; (D) Nepeta binaloudensis Jamzad, a highly endangered medicinal plant found in NE of Iran; (E) Rheum turkestanicum Janisch., a rare important medicinal plant distributed in NE of Iran; (F) Dorema aucheri Boiss., a threatened medicinal plant found in the western region of Iran; (G) Kelussia odoratissima Mozaff., a threatened medicinal species occurs in a small area in the western part of Iran; (H) Fritillaria imperialis L., a threatened medicinal plant distributed in the western region of Iran.

natural plant products. Evaluating and monitoring potentially detrimental substances are indispensable for improving the general quality and safety of extensively employed medicinal herbs.

It was found that majority of ethnobotanical studies reported in Iran suffer from insufficient statistical data. Therefore, modern ethnobotanical attempts with new methods for data analysis should continue, mainly in areas that have so far received fewer attention, particularly on multiethnic regions. The fastest manner to species selection for biological, phytochemical and pharmacological investigations, is by reviewing the ethnobotanical literature that accentuate the significance of such studies.

The absence of accurate translation and interpretation of the old traditional books is a key challenge in the verification of herbal materials used. In Iran, scientists are studying medicinal plants with reference to their therapeutic uses as documented in old books. Therefore, the improvement of ethnobotanical studies in Iran and correct scientific identification of medicinal plant species in the texts, need more involvement of botanists and experienced plant taxonomists.

Another major concern that remains is conservation status of medicinal plant species. Many Iranian medicinal plants are collected from the wild habitats, and they are becoming endangered at an alarming rate. The occurrence of threatened medicinal plants subjected to high anthropogenic pressure on these taxa. Some of these invaluable species have very limited distribution in the country and need special conservation strategies for their survival. If overexploitation and habitat destruction of such invaluable medicinal plants continues, they may vanish from the area within a few years. 
The chemical variety of secondary metabolites from the plant kingdom, provide limitless opportunities for novel drug discovery. Recent investigations revealed that rare and endemic medicinal plants of Iran are rich in potent secondary metabolites that would serve as promising precursors for developing potent plant-based drugs. There is no doubt that Iranian Traditional Medicine, together with endemic medicinal species in Iran, includes a golden source of potential modern drugs and health products. Hence, we suggest that Iranian rare endemic taxa reported with high medicinal value should be involved in cultivation practices for their sustainable usage and also should be engaged in subsequent pharmacological studies and clinical trials in order to evaluate efficacy and safety of their traditional uses.

Overall, notwithstanding the achievements of conventional medicine, the Iranian people continues to actively use medicinal plants for health improvement and it is foreseen that in the near future, the Persian traditional herbal remedies will be incorporated into the modern allopathic medicine. Therefore, more collaborative attempts of Iranian ethnobotanists, phytochemists, pharmacists and physicians could be a practical strategy to channel the gap between the traditional plant based healing practices, laboratories and clinics.

To conclude, this study reviewed the status, advantages and challenges of Iranian traditional medicinal plants in order to raise public awareness and improve further scientific works. Considering the increasing demand of medicinal plants and existence of several critical concern over the herbal products in Iran, it will be vital to have quality control standards and legitimate regulation of medicinal plants throughout supply chain from plant raw materials to the end product to reorganize Iranian Traditional Medicinal plants and phytotherapy sector and to ensure health and safety of consumers.

\section{Acknowledgements}

We are grateful to all the authors of the various literature sources consulted and to all the informants who freely shared their information with us. This project is supported by Payame Noor University and we appreciate the support.

\section{Conflict of interests}

The authors declare no conflict of interest.

\section{References}

1. Noroozi J, Talebi A, Doostmohammadi M, Manafzadeh S, Asgarpour Z, Schneeweiss GM. Endemic diversity and distribution of the Iranian vascular flora across phytogeographical regions, biodiversity hotspots and areas of $\begin{array}{lll}\text { endemism. } & \text { Sci } & \text { Rep. }\end{array}$ https://doi.org/10.1038/s41598-019-49417-1

2. Zohary M. Geobotanical foundations of the Middle East: Fischer; 1973.p.765.

3. Léonard J. Contribution a l'étude de la flore et de la végétation des desert d'Iran, Fascicule 8: Étude des aries de distribution,
Les phytochories, Les chorotypes. Bull Jard Bot Natl Belg. 1988.p.190.

4. Akhani H, Deil U. First observations on the flora and vegetation of three islands in the NW Persian Gulf (Iran). Phyton. 2012;52(1):73-99.

5. Christenhusz MJ, Byng JW. The number of known plants species in the world and its annual increase. Phytotaxa. 2016;261(3):201-17. https://doi.org/10.11646/phytotaxa.261.3.1

6. Pan S-Y, Litscher G, Gao S-H, Zhou S-F, Yu Z-L, Chen H-Q, et al. Historical perspective of traditional indigenous medical practices: the current renaissance and conservation of herbal resources. Evid Based Complement Alternat Med. 2014;1-21. https://doi.org/10.1155/2014/525340

7. Ghahremaninejad F, Ataei N, Nejad Falatoury A. Comparison of angiosperm flora of Afghanistan and Iran in accordance with APG IV system. Nova Biol Reperta. 2017;4(1):74-99. https:// doi.org/10.21859/acadpub.nbr.4.1.74

8. Mozaffarian V. Identification of medicinal and aromatic plants of Iran: éditeur non identifié; 2013.p.1444.

9. Amiri MS, Joharchi MR, Nadaf M, Nasseh Y. Ethnobotanical knowledge of Astragalus spp.: The world's largest genus of vascular plants. Avicenna J Phytomed. 2020;10(2):128-42. https://doi.org/10.22038/AJP.2019.14240

10. Jan HA, Jan S, Bussmann RW, Wali S, Sisto F, Ahmad L. Complementary and alternative medicine research, prospects and limitations in Pakistan: A literature review. Acta Ecol Sin. 2019 .

11. Amiri MS, Joharchi MR. Ethnobotanical investigation of traditional medicinal plants commercialized in the markets of Mashhad, Iran. Avicenna J Phytomed. 2013;3(3):254-71. https:// doi.org/10.22038/AJP.2013.487

12. Bussmann RW. Ethnobotany and biodiversity conservation. Mod Trends Appl Terr Ecol: Springer; 2002;343-60. https://doi.org/10.1007/978-1-4615-0223-4_18

13. Mahomoodally MF. Traditional medicines in Africa: an appraisal of ten potent African medicinal plants. Evid Based $\begin{array}{llll}\text { Complement } & \text { Alternat } & \text { Med. } & \end{array}$ https://doi.org/10.1155/2013/617459

14. Ayati MH, Pourabbasi A, Namazi N, Zargaran A, Kheiry Z, Kazemi $\mathrm{AH}$, et al. The necessity for integrating traditional, complementary and alternative medicine into medical education curricula in Iran. J Integr Med. 2019;17(4):296-301. https://doi.org/10.1016/j.joim.2019.04.005

15. Akaberi M, Boghrati Z, Amiri MS, Emami SA. Saffron: The Golden Spice. Science of Spices and Culinary Herbs-Latest Laboratory, Preclinical and Clinical Studies. 2019;1:1-29. https://doi.org/10.2174/9781681087511119010003

16. Pourahmad J. History of medical sciences in Iran. Iranian J Pharm Res. 2010(2):93-99. https://doi.org/10.22037/ijpr.2010.750

17. Mohammadhosseini M, Sarker SD, Akbarzadeh A. Chemical composition of the essential oils and extracts of Achillea species and their biological activities: A review. J Ethnopharmacol. 2017;199:257-315 https://doi.org/10.1016/j.jep.2017.02.010

18. Khojimatov OK, Khamraeva DT, Khujanov AN, Bussmann RW An overview of Ethnomedicinal plants of Uzbekistan. Ethnobot Res Appl. 2020;20:1-19. https://doi.org/10.32859/era.20.08.1-19

19. Saeidnia S, Gohari AR, Manayi A, Kourepaz-Mahmoodabadi M. Satureja: ethnomedicine, phytochemical diversity and pharmacological activities: Springer. 2015 https://doi.org/10.1007/978-3-319-25026-7

20. Jennings HM, Merrell J, Thompson JL, Heinrich M. Food or medicine? The food medicine interface in households in Sylhet. J Ethnopharmacol. 2015;167:97-104 https://doi.org/10.1016/j.jep.2014.09.011

21. Sadeghi Z, Akaberi M, Sobhkhizi A, Sahebkar A, Emami SA. Evaluation the ethno pharmacological studies in Iran during 2004-2016: A systematic review. J Cell Physiol. 2018;233(2):91423. https://doi.org/10.1002/jcp.25803

22. Maleki T, Akhani H. Ethnobotanical and ethnomedicinal studies in Baluchi tribes: A case study in Mt. Taftan, 
southeastern Iran. J Ethnopharmacol. 2018;217:163-77. https:// doi.org/10.1016/j.jep.2018.02.017

23. Nasab FK, Khosravi AR. Ethnobotanical study of medicinal plants of Sirjan in Kerman Province, Iran. J Ethnopharmacol. 2014;154(1):190-97. https://doi.org/10.1016/j.jep.2014.04.003

24. Zargari A. Medicinal plants, Vol 1; Tehran. Tehran university press; 1990.

25. Hooper D, McNair JB, Field H. Useful plants and drugs of Iran and Iraq: Field Museum of Natural History. 1937. https://doi.org/10.5962/bhl.title.2281

26. Ghorbani A. Studies on pharmaceutical ethnobotany in the region of Turkmen Sahra, north of Iran:(Part 1): General results. J Ethnopharmacol. 2005;102(1):58-68.

27. Sajjadi S, Batooli H, Ghanbari A. Collection, evaluation and ethnobotany of Kashan medicinal plants. 2011. https://doi.org/ 10.1016/j.jep.2005.05.035

28. Emami S, Nadjafi F, Amine G, Amiri MS, Khosravi Mt NM. Les espèces de plantes médicinales utilisées par les guérisseurs traditionnels dans la province de Khorasan, nord-est de l'Iran. J Ethnopharmacol. 2012;48:48-59.

29. Rajaei P, Mohamadi N. Ethnobotanical study of medicinal plants of Hezar mountain allocated in south east of Iran Iranian J Pharm Res. 2012;11(4):1153-67. https://doi.org/10.22037/IJPR.2012.1207

30. Amiri MS, Jabbarzadeh P, Akhondi M. An ethnobotanical survey of medicinal plants used by indigenous people in Zangelanlo district, Northeast Iran. J Med Plants Res. 2012;6(5):749-53. https://doi.org/10.5897/JMPR11.1280

31. Amiri MS, Joharchi MR. Ethnobotanical knowledge of Apiaceae family in Iran: A review. Avicenna J Phytomed. 2016;6(6):62135. https://doi.org/10.22038/AJP.2016.6696

32. Amiri MS, Joharchi MR, TaghavizadehYazdi ME. Ethnomedicinal plants used to cure jaundice by traditional healers of Mashhad, Iran. Iranian J Pharm Res. 2014;13(1):157-62. https://doi.org/10.22037/IJPR.2014.1445

33. Nadaf M, Joharchi M, Amiri MS. Ethnomedicinal uses of plants for the treatment of nervous disorders at the herbal markets of Bojnord, North Khorasan Province, Iran. Avicenna J Phytomed. 2019;9(2):153-63. https://doi.org/10.22038/AJP.2018.11778

34. WHO (World Health Oranization). International Classification of Diseases (ICD) Information Sheet. (http://www.who.int/classifications/icd/factsheet/en/). 2017.

35. Ghorbani A, Naghibi F, Mosadegh M. Ethnobotany, ethnopharmacology and drug discovery. Iran J Pharm Sci. 2006;2(2):109-18.

36. Sadeghi Z, Mahmood A. Ethno gynecological knowledge of medicinal plants used by Baluch tribes, southeast of Baluchistan, Iran. Rev Bras Farmacogn. 2014;24(6):706-15. https://doi.org/10.1016/j.bjp.2014.11.006

37. Mirdeilami SZ, Barani H, Mazandarani M, Heshmati GA. Ethnopharmacological survey of medicinal plants in Maraveh Tappeh region, North of Iran. 2011;327-38.

38. Minooeianhaghighi M, Sepehrian L, Shokri H. Antifungal effects of Lavandula binaludensis and Cuminum cyminum essential oils against Candida albicans strains isolated from patients with recurrent vulvovaginal candidiasis. J Mycol Med. 2017;27(1):65-71. https://doi.org/10.1016/j.mycmed.2016.09.002

39. Mozaffarian V. A Dictionary of Iranian Plant Names. Tehran: Farhang Moaser Pub, 1996. Persian.

40. Podlech D, Zarre S, Ekici M, Maassoumi A, Sytin A. A taxonomic revision of the genus Astragalus L. (Leguminosae) in the Old World. Ann Nat Hist Mus Wien Ser B Bot Zool. 2014.p.2439.

41. Joharchi MR, Amiri MS. Taxonomic evaluation of misidentification of crude herbal drugs marketed in Iran Avicenna J Phytomed. 2012;2(2):105-12. https://doi.org/10.22038/AJP.2012.41

42. Hussain S, Hamid A, Ahmad KS, Mehmood A, Nawaz F, Ahmed H. Quantitative ethnopharmacological profiling of medicinal shrubs used by indigenous communities of Rawalakot, District Poonch, Azad Jammu and Kashmir, Pakistan. Rev Bras
Farmacogn.

https://doi.org/10.1016/j.bjp.2019.06.008

2019;29(5):665-76

43. Kayani S, Ahmad M, Sultana S, Shinwari ZK, Zafar M, Yaseen G, et al. Ethnobotany of medicinal plants among the communities of Alpine and Sub alpine regions of Pakistan. J Ethnopharmacol. https://doi.org/10.1016/j.jep.2015.02.004

44. Yazdi MET, Khara J, Husaindokht MR, Reza H, Sadeghnia SEB, Amiri MS, et al. Biocomponents and Antioxidant Activity of $\begin{array}{ll}\text { Ribes } \quad \text { khorasanicum. 2018;3(3):99-103. } & \text {. }\end{array}$ https://doi.org/10.15171/ijbsm.2018.18

45. Taghavizadeh Yazdi ME, Hamidi A, Amiri MS, Kazemi Oskuee R, Hosseini HA, Hashemzadeh A, et al. Eco friendly and plantbased synthesis of silver nanoparticles using Allium giganteum and investigation of its bactericidal, cytotoxicity and photocatalytic effects. Mater Technol. 2019;34(8):490-97. https://doi.org/10.1080/10667857.2019.1583408

46. Modarres M, Bahabadi SE, Yazdi MET. Enhanced production of phenolic acids in cell suspension culture of Salvia leriifolia Benth. using growth regulators and sucrose. Cytotechnology. 2018;1-10. https://doi.org/10.1007/s10616-017-0178-0

47. Khan MSA, Ahmad I. Herbal medicine: current trends and future prospects. New Look Phytomed: Elsevier. 2019;3-13.

48. Nirmala MJ, Samundeeswari A, Sankar PD. Natural plant resources in anti-cancer therapy-A review. Res Plant Biol. 2011;1(3)

49. Munhoz A, Frode TS. Isolated compounds from natural products with potential antidiabetic activity-A systematic review. Curr Diabetes Rev. 2018;14(1):36-106. https://doi.org/10.2174/1573399813666170505120621

50. Emami SA, Amin-Ar-Ramimeh E, Ahi A, Bolourian Kashy MR Schneider B, Iranshahi M. Prenylated flavonoids and flavonostilbenes from Sophora pachycarpa roots. Pharm Biol. 2007;45(6):453-57.

51. Karamoddini MK, Emami SA, Ghannad MS, Sani EA, Sahebkar A. Antiviral activities of aerial subsets of Artemisia species against Herpes simplex virus type 1 (HSV1) in vitro. Asian Biomed. 2011;5(1):63-68. https://doi.org/10.5372/1905 7415.0501.007

52. Tayarani-Najarani Z, Asili J, Parsaee H, Mousavi SH, Mashhadian NV, Mirzaee A, et al. Wogonin and neobaicalein from Scutellaria litwinowii roots are apoptotic for HeLa cells. Rev Bras Farmacogn. 2012;22(2):268-76. https://doi.org/10.1590/ S0102-695X2011005000161

53. Shiezadeh F, Mousavi SH, Amiri MS, Iranshahi M, TayaraniNajaran Z, Karimi G. Cytotoxic and apoptotic potential of Rheum turkestanicum Janisch root extract on human cancer and normal cells. Iranian J Pharm Res. 2013;12(4):811-19.

54. Sonboli A, Mirzania F, Aliahmadi A, Amiri MS. Composition and antibacterial activity of the essential oil of Phlomidoschema parviflorum from Iran. Chem Nat Compd. 2015;51(2):366-8. https://doi.org/10.1007/s10600-015-1286-8

55. Tayarani-Najaran Z, Akaberi M, Vatani M, Emami SA. Evaluation of antioxidant and anti melanogenic activities of different extracts from aerial parts of Nepeta binaludensis Jamzad in murine melanoma B16F10 cells. Iran J Basic Med Sci. 2016;19(6):662-69. https://doi.org/10.22038/IJBMS.2016.7135

56. Forouzanfar F, Hosseini A, Amiri MS, Rakhshandeh $\mathrm{H}$ Potentiating effects of Perovskia abrotanoides Karel. on pentobarbital induced sleep. Avicenna J Phytomed. 2017;7(3):214-222. https://doi.org/10.22038/ajp.2016.7793

57. Sharififar F, Moharam KM, Moattar F, Babakhanloo P, Khodami M. Ethnobotanical study of medicinal plants of Joopar Mountains of Kerman province, Iran. 2014.

58. Hosseini A, Mollazadeh H, Amiri MS, Sadeghnia HR, Ghorbani A. Effects of a standardized extract of Rheum turkestanicum Janischew root on diabetic changes in the kidney, liver and heart of streptozotocin induced diabetic rats. Biomed Pharmacother. https://doi.org/10.1016/j.biopha.2016.12.059

59. Mohamadi N, Rajaei P, Moradalizadeh M, Amiri MS. Essential oil composition and antioxidant activity of Levisticum officinale Koch. at various phenological stages. 2017. 
60. Pourgonabadi S, Amiri MS, Mousavi SH. Cytotoxic and apoptogenic effects of Bryonia aspera root extract against Hela and HN-5 cancer cell lines. Avicenna J Phytomed. 2017;7(1):6672. https://doi.org/10.22038/AJP.2016.6352

61. Dehghan H, Salehi P, Amiri MS. Bioassay-guided purification of a-amylase, a-glucosidase inhibitors and DPPH radical scavengers from roots of Rheum turkestanicum. Ind Crops Prod. 2018;117:303-39. https://doi.org/10.1016/j.indcrop.2018.02.086

62. Hamidi A, Yazdi MET, Amiri MS, Hosseini HA, Darroudi M. Biological synthesis of silver nanoparticles in Tribulus terrestris L. extract and evaluation of their photocatalyst, antibacterial and cytotoxicity effects. Res Chem Intermed 2019;45(5):2915-25. https://doi.org/10.1007/s11164-019-03770-y

63. Karimzadeh SM, Moridi Farimani M, Amiri MS, Tabefam M, Alilou M, Stuppner H. Perovskanol, a new sesquiterpenoid with an unprecedented skeleton from Perovskia abrotanoides.
Prod
Res.
2019;1-5. https://doi.org/10.1080/14786419.2019.1684280

64. Jahani Yazdi A, Javanshir S, Soukhtanloo M, Jalili-Nik M, Jafarian AH, Iranshahi M et al. Acute and sub-acute toxicity evaluation of the root extract of Rheum turkestanicum Janisch. Drug Chem $\quad$ Toxicol. 2019;1-7. https://doi.org/10.1080/01480545.2018.1561713

65. Yazdi MET, Amiri MS, Hosseini HA, Oskuee RK, Mosawee H, Pakravanan $\mathrm{K}$ et al. Plant based synthesis of silver nanoparticles in Handelia trichophylla and their biologica activities. Bull Mater Sci. 2019;42(4):155. https://doi.org/10.1007/s12034-019-1855-8

66. Darroudi M, Yazdi MET, Amiri MS. Plant-Mediated Biosynthesis of Nanoparticles. 21st Century Nanoscience-A Handbook: CRC Press; 2020;1-18.

67. Akaberi M, Danton O, Tayarani-Najaran Z, Asili J, Iranshahi M, Emami SA, et al. HPLC-based activity profiling for antiprotozoal compounds in the endemic Iranian medicinal plant Helichrysum oocephalum. J Nat Prod. 2019;82(4):958-69. https://doi.org/10.1021/acs.jnatprod.8b01031

68. Tayarani-Najaran Z, Emami SA. Cytotoxic plants: potential uses in prevention and treatment of cancer. Current Cancer Treatment-Novel Beyond Conventional Approaches: IntechOpen. 2011. https://doi.org/10.5772/22108

69. Es-haghi A, Javadi F, Yazdi MET, Amiri MS. The Expression of Antioxidant Genes and Cytotoxicity of Biosynthesized Cerium Oxide Nanoparticles Against Hepatic Carcinoma Cell Line. Avicenna J Med Biochem. 2019;7(1):16-20. https://doi.org/10.34172/ajmb.2019.04

70. Mojab F. Pharmacognosy in Iran. Iranian J Pharm Res. 2010(3):153-54. https://doi.org/10.22037/IJPR.2010.669

71. Ghorbani A, Saeedi Y, De Boer HJ. Unidentifiable by morphology: DNA barcoding of plant material in local markets in Iran. PloS One. 2017;12(4):e0175722. https://doi.org/10.1371/journal.pone.0175722

72. Mishra P, Kumar A, Nagireddy A, Mani DN, Shukla AK, Tiwar $\mathrm{R}$, et al. DNA barcoding: an efficient tool to overcome authentication challenges in the herbal market. Plant Biotechnol J. 2016;14(1):8-21. https://doi.org/10.1111/pbi.12419

73. Raclariu AC, Heinrich M, Ichim MC, de Boer H. Benefits and limitations of DNA barcoding and metabarcoding in herbal product authentication. Phytochem Anal. 2018;29(2):123-28. https://doi.org/10.1002/pca.2732

74. Mukherjee PK, Pitchairajan V, Murugan V, Sivasankaran P, Khan Y. Strategies for revitalization of traditional medicine. Chin Herb $\quad$ Med. 2010;2(1):1-15 https://doi.org/10.3969/j.issn.1674-6384.2010.01.001

75. Jiang C, Cao L, Yuan Y, Chen M, Jin Y, Huang L. Barcoding melting curve analysis for rapid, sensitive and discriminating authentication of saffron (Crocus sativus L.) from its adulterants. BioMed Res Int. 2014;1-10. https://doi.org/10.1155/2014/809037

76. Hebert PD, Cywinska A, Ball SL, Dewaard JR. Biological identifications through DNA barcodes. Proc R Soc 2003;270(1512):313-21. https://doi.org/10.1098/rspb.2002.2218
77. Babaei S, Talebi M, Bahar M. Developing an SCAR and ITS reliable multiplex PCR-based assay for safflower adulterant detection in saffron samples. Food Control. 2014;35(1):323-28. https://doi.org/10.1016/j.foodcont.2013.07.019

78. De Boer HJ, Ghorbani A, Manzanilla V, Raclariu A-C, Kreziou A Ounjai S, et al. DNA metabarcoding of orchid derived products reveals widespread illegal orchid trade. Proc $\mathrm{R}$ Soc 2017;284(1863):20171182. https://doi.org/10.1098/rspb.2017.1182

79. Graz B. What is "clinical data"? Why and how can they be collected during field surveys on medicinal plants? Ethnopharmacol. https://doi.org/10.1016/j.jep.2013.08.036

80. Street R, Stirk W, Van Staden J. South African traditional medicinal plant trade challenges in regulating quality, safety and efficacy. J Ethnopharmacol. 2008;119(3):705-10. https://doi.org/10.1016/j.jep.2008.06.019

81. Chikezie P, Ibegbulem C, Mbagwu F. Medicinal potentials and toxicity concerns of bioactive principles. Med Aromat Plants. 2015;4(3):1-15.

82. Delirrad M, Ghasempour Z, Hassanzadazar H, Roshani Y, Mohammadi D, Forouzan S, et al. Determination of methanol content in herbal distillates produced in Urmia using spectrophotometry. Iran J Toxicol. 2012;6(16):594-99.

83. Mousavi SR, Namaei-Ghassemi M, Layegh M, AfzalAghaee M. Determination of methanol concentrations in traditional herbal waters of different brands in Iran. Iran J Basic Med Sci. 2011;14(4):361-68.

84. Atanasov AG, Waltenberger B, Pferschy-Wenzig E-M, Linder T, Wawrosch C, Uhrin P, et al. Discovery and resupply of pharmacologically active plant derived natural products: a review. Biotechnol Adv. 2015;33(8):1582-614. https://doi.org/10.1016/j.biotechadv.2015.08.001

85. Wink M. Modes of action of herbal medicines and plant secondary metabolites. Medicine. 2015;2(3):251-86. https://doi.org/10.3390/medicines2030251

86. Mehrabani M, Ghanadi A, Sajjadi E, Ghassemi N, Shams AM. Toxic pyrrolizidine alkaloids of Echium amoenum Fisch. \& Mey. 2006;14(3):122-27.

87. Pasalar M, Daneshfard B, Lankarani KB. Complementary and alternative medicine related drug induced liver injury in Iran. J clin transl hepatol. 2020;8(1):106-07. https://doi.org/10.14218/jcth.2020.00008

88. Jalili A, Jamzad Z. A preliminary survey of endemic, rare and endangered plant species in Iran. Research Institute of Forests and Rangelands IR. 1999.p.759.

89. Memariani F, Akhani H, Joharchi MR. Endemic plants of Khorassan-Kopet Dagh floristic province in Irano-Turanian region: diversity, distribution patterns and conservation status. Phytotaxa. 2016;249(1):31-117.

90. Chen S-L, Yu H, Luo H-M, Wu Q, Li C-F, Steinmetz A. Conservation and sustainable use of medicinal plants: problems, progress and prospects. Chin Med. 2016;11(1):37. https://doi.org/10.1186/s13020-016-0108-7

91. Ayati Z, Amiri MS, Ramezani M, Delshad E, Sahebkar A, Emami SA Phytochemistry, traditional uses and pharmacological profile of rose hip: A review. Curr Pharm Des. 2018;24(35):4101-24. https://doi.org/10.2174/1381612824666181010151849

92. Akaberi M, Boghrati Z, Amiri MS, Khayyat MH, Emami SA. A Review of Conifers in Iran: Chemistry, biology and their importance in traditional and modern medicine. Curr Pharm Des 2020:26(14):1584-613. https://doi.org/10.2174/1381612826666200128100023

93. Zibaee E, Kamalian S, Tajvar M, Amiri MS, Ramezani M, Moghadam AT, et al. Citrus species: A review of traditional uses, phytochemistry and pharmacology. Curr Pharm Des. 2020; 26(1):44-97. https://doi.org/10.2174/1381612825666191127115601

94. Ramezani M, Amiri MS, Zibaee E, Boghrati Z, Ayati Z, Sahebkar A, et al. A review on the phytochemistry, ethnobotanical uses and pharmacology of Borago species. Curr Pharm Des. 2020;26(1):110-28.

https://doi.org/10.2174/1381612825666191216152733 
95. Ghorbani A, Amiri MS, Hosseini A. Pharmacological properties of Rheum turkestanicum Janisch. Heliyon. 2019;5(6):e01986. https://doi.org/10.1016/j.heliyon.2019.e01986

96. Yazdi MET, Khara J, Sadeghnia HR, Bahabadi SE, Darroudi M. Biosynthesis, characterization and antibacterial activity of silver nanoparticles using Rheum turkestanicum shoots extract. Res Chem Intermed. 2018;44(2):1325-34 https://doi.org/10.1007/s11164-017-3169-z

97. Yazdi MET, Khara J, Housaindokht MR, Sadeghnia HR, Bahabadi SE, Amiri MS, et al. Role of Ribes khorassanicum in the biosynthesis of AgNPs and their antibacterial properties. IET Nanobiotechnol. 2018;13(2):189-92. https://doi.org/10.1049/iet-nbt.2018.5215

98. Yazdi T, Ehsan M, Housaindokht MR, Sadeghnia HR Esmaeilzadeh Bahabadi S, Amiri MS, et al. Assessment of phytochemical components and antioxidant activity of Rheum turkestanicum Janisch. Stud Med Sci. 2020;31(2):75-81.

99. Sobhani Z, Nikoofal-Sahlabadi S, Amiri MS, Ramezani M, Emami SA, Sahebkar A. Therapeutic effects of Ziziphus jujuba Mill. fruit in traditional and modern medicine: a review. Med Chem. 2019. https://doi.org/10.2174/1573406415666191031143553

100. Tavassoli AP, Anushiravani M, Hoseini SM, Nikakhtar Z, Baghdar HN, Ramezani M, et al. Phytochemistry and therapeutic effects of Alhagi spp. and Tarangabin in traditional and modern medicine: a review. J HerbMed Pharmacol. 2020;9(2):86-104. https://doi.org/10.34172/jhp.2020.13

101. Ayati Z, Ramezani M, Amiri MS, Moghadam AT, Rahimi H, Abdollahzade A, et al. Ethnobotany, phytochemistry and traditional uses of Curcuma spp. and pharmacological profile of two important species (C. longa and C. zedoaria): a review. Curr Pharm Des. 2019;25(8):871-935. https://doi.org/10.2174/1381612825666190402163940

102. Mosaddegh M, Naghibi F, Moazzeni H, Pirani A, Esmaeili S Ethnobotanical survey of herbal remedies traditionally used in Kohghiluyeh va Boyer Ahmad province of Iran. J Ethnopharmacol. 2012;141(1):80-95 https://doi.org/10.1016/j.jep.2012.02.004

103. Khodayari H, Amani S, Amiri H. Ethnobotanical study of medicinal plants in different regions of Khuzestan province. 2015;4(8):12-26.

104. Hosseini A, Bakhtiari E, Rad AK, Shahraki S, Mousavi SH, Havakhah S, et al. The evaluation and comparing of cytotoxic effects of Ferula gummosa gum, Scutellaria lindbergii, Kelussia odoratissima and Artemisia kopetdaghensis extracts on ACHN cell line. Iranian J Pharm Res. 2017;16(3):1104-12.

105. Naghibi F, Mosadegh M, Mohammadi MS, Ghorbani A. Labiatae family in folk medicine in Iran: from ethnobotany to pharmacology. Iranian J Pharm Res. 2005;4(2):63-79.

106. Safa O, Soltanipoor MA, Rastegar S, Kazemi M, Dehkordi KN Ghannadi A. An ethnobotanical survey on hormozgan province, Iran. Avicenna J Phytomed. 2013;3(1):64-81.

107. Farahmand H, Nazari F. Environmental and anthropogenic pressures on geophytes of Iran and the possible protection strategies: a review. Int J Hort Sci Tech. 2015;2(2):111-32. https://doi.org/10.22059/IJHST.2015.56429 